\title{
Deprecjacja wielkiego jubileuszu: obchody 1150-lecia rosyjskiej państwowości w Nowogrodzie Wielkim (2012)*
}

Zarys treści: Artykuł jest poświęcony obchodom 1150-lecia rosyjskiej państwowości, które przypadły na wrzesień 2012 r. Za punkt odniesienia dla retoryki inicjatora uroczystości, prezydenta Federacji Rosyjskiej D. Miedwiediewa, obrano liberalną publicystykę towarzyszącą pierwowzorowi jubileuszu z 1862 r. Zabieg ten podyktował fakt częstego odwoływania się przez ówczesnego przywódcę Rosji do „epoki wielkich reform” (lata 60. i 70. XIX w.). W tekście omówiony został przebieg jubileuszu oraz poświęcony mu w środkach masowej informacji przekaz medialny. Zaprezentowano również nieudaną inicjatywę ustawodawczą służącą uznaniu symbolicznej rocznicy początków Rusi za święto narodowe.

Outline of content: The article is devoted to the subject of the 1150th anniversary of the Russian Statehood celebrated in September 2012. It was the liberal political commentary writings accompanying the original model of the jubilee celebrated in 1862 that was used as the point of reference of the rhetoric of the celebrations' initiator, the President of Russian Federation Dmitry Medvedev. This made the president of Russia to refer very often to the "Era of the Great Reforms" (the 1860s, and 1870s). The article describes the course of the jubilee celebrations with accompanying information campaign in the public mass media, as well as a failed legislative action to make the symbolic anniversary of the origins of the Russian Statehood a National Day.

Słowa kluczowe: Rosja, liberalizm, upamiętnienie, jubileusz, pamięć zbiorowa, Aleksander II, Dymitr Miedwiediew

Keywords: Russia, liberalism, commemoration, jubilee, collective memory, Alexander II, Dmitry Medvedev

* Artykuł powstał w ramach projektu badawczego Histories and Memories of Empires in Eastern Europe: Interactive Studies, kierowanego przez prof. dr. hab. Andrzeja Nowaka. W latach 2012-2014 autor był stypendystą programu MISTRZ, finansowanego przez Fundację na rzecz Nauki Polskiej. 
Ukończone tysiąc lat! Jak bardzo istotne jest znaczenie minut [jubileuszu]! Mimowolnie przez naszą wyobraźnię sunie łańcuch przetaczających się wydarzeń, kroczą rzędy przychodzących sobie na zmianę pokoleń, spod wiekowych prochów zapomnianych mogił zmartwychwstają męczennicy świata, męczennicy prawdy, bojownicy woli, bohaterowie wiary i myśli, wybitne indywidualności - przywódcy mas, bezbarwne masy nieświadomie kroczące śladami nici przewodniej, odciśniętymi wbrew ich pragnieniu... Stary żywot zrzuca z siebie wiekową pleśń; słyszymy jęki wcześnie przekwitłych nadziei, daremnie zmarnotrawionych sił, lament milionów cierpiętników, którzy zginęli w epokach ciężkich nieszczęść, bez udziału współczesnych, nieopłakanych przez potomstwo i zapomnianych przez historię - zwierzęce rozpasanie samowoli, cichy smutek beznadziejnego cierpienia ${ }^{1}$.

N. Kostomarow

W świecie XXI wieku na tle nowego układu sił ekonomicznych, cywilizacyjnych, wojskowych, Rosja powinna być państwem suwerennym i wpływowym. Powinniśmy nie tylko pewnie się rozwijać, ale i zachować swoją narodową i duchową tożsamość, nie zatracić siebie jako naród. Być i pozostawać Rosją. [...] Dla odrodzenia świadomości narodowej musimy połączyć w jedno epoki historyczne i powrócić do rozumienia tej prostej prawdy, że Rosja zaczęła się nie w 1917 i nawet nie w 1991 r., że mamy jedną, nierozerwalną tysiącletnią historię. Opierając się na niej, zyskujemy wewnętrzną siłę i sens rozwoju narodowego².

W. Putin

\section{Uwagi wstępne}

Nowocześnie uprawiana historia polityczna nie może zbywać milczeniem osiągnięć dziedzin pokrewnych, osobliwie antropologii historycznej, która epicentrum swojego zainteresowania lokuje w sferze kultury, obejmującej zagadnienia społeczno-polityczne i ekonomiczne. Najnowsza historiografia Rosji słusznie przydaje duże znaczenie ludzkim wyobrażeniom i wszystkiemu, co sprzyja ich kreowaniu zgodnie z życzeniem władzy, wpierającej się wszak nie tylko (i nawet nie zwłaszcza) na przymusie, lecz także na autorytecie ${ }^{3}$. Każda poważna próba opisania fenomenu władzy musi uwzględniać kulturowe mechanizmy jej funkcjonowania i jej reprezentacje. Ściśle biorąc, tematyka ta nie jest nowa i już Max Weber uczynił legitymizację centralnym problemem nauk społecznych. Ujęcie to zakłada, iż używana przez rządzących symbolika ma za zadanie wzmacniać wiarę rządzonych w oficjalnie deklarowane wartości, na jakich wspiera się ład polityczny ${ }^{4}$.

${ }^{1}$ Н.И. Костомаров, Тысячелетие, „Санкт-петербургские ведомости” 5 (9.01.1862), s. 24.

2 В.В. Путин, Послание Президента Федеральному Собранию, 12 декабря 2012 года, http:// kremlin.ru/events/president/news/17118 (dostęp: 3.09.2014).

3 J. Baszkiewicz, Władza, Wrocław 1999, zwł. s. 5-7.

4 М.М. Кром, Политическая антропология: новые подходы $\kappa$ изучению феномена власти в истории России, „Исторические записки” 122 (2001), z. 4, s. 374-376; K. Pomian, Historia - dziś, w: Historia - dziś. Teoretyczne problemy wiedzy o przeszłości, red. E. Domańska, R. Stobiecki, T. Wiślicz, Kraków 2014, s. 21-22. 
Niniejszy tekst ma na celu przybliżyć obchody 1150-lecia państwowości rosyjskiej - rocznicy zdawałoby się fundamentalnie ważnej dla świadomości historycznej Rosjan i dla elit sprawujących władzę. Organizatorzy wielkich jubileuszów nie przykładali szczególnej wagi do sprostowań historyków, kwestionujących niekiedy poprawność wyliczeń autora(ów) Powieści minionych lat, który swoim autorytetem nakazał uznać 862 r. za moment inicjacyjny. Trudno zresztą dziwić się tej dezynwolturze dla chronologicznej precyzji: definitywne rozstrzygnięcie, kiedy miał miejsce początek, być może nigdy nie nastąpi i nie ma pierwszorzędnego znaczenia. Wszak nie o punkt na osi czasu tu chodzi, lecz o to, co w drugim dziesiątku stuleci istnienia Rosji wynika z tak długiego trwania. Rzecz ciekawa: musiało upłynąć całe tysiąclecie, zanim w kontekście początkowej daty postawiono sobie to pytanie. Rzecz jeszcze ciekawsza: zdarzyło się to w czasie, gdy Imperium Rosyjskie wkraczało na nową drogę, czyli w „epoce wielkich reform”. Na paradoks zakrawa, że „nowoczesność zwraca się w stronę przeszłości. Jeśli odrzuca to, co dawne, próbuje schronić się w historii”" Zapoznanie się z ówczesną rosyjską recepcją przeszłości samo w sobie wydaje się frapujące poznawczo. Czemu miałoby służyć włączanie do analizy kolejnych obchodów, zorganizowanych w całkowicie odmiennych warunkach historycznych? Uzasadnieniem niech będzie stwierdzenie brytyjskiego antropologa i socjologa Paula Connertona, który w klasycznej już pracy sprzed ćwierćwiecza napisał, że „do najważniejszych samointerpretacji [społeczeństwa] należą tworzone i podtrzymywane przez każdą wspólnotę obrazy jej samej i właściwej jej ciągłości”' . Otóż uroczystości zorganizowane w 2012 r. wprost nawiązywały do obchodów sprzed stu pięćdziesięciu lat, tym samym osadzając aktualne wysiłki $\mathrm{w}$ tradycji i kontynuując (rozwijając) modernizacyjną narrację doby Aleksandra II.

Poruszając się w kręgu zagadnień dotyczących powiązań między tradycją i nowoczesnością, nie sposób przemilczeć poniższe pytanie: na czym zasadza się związek modernizacyjnych zadań z polityką historyczną? Z punktu widzenia władzy reformującej państwo przeszłość jest bezcennym zasobem służącym mobilizacji społecznej; wiadomo bowiem, że bez współudziału zwykłych ludzi przemiany nie powiodą się, metody administracyjne nie wystarczą. Ilja Kalinin, historyk związany z Sankt-Petersburskim Uniwersytetem Państwowym, przypisując rosyjskiej elicie rządzącej „suwerenny monopol interpretacji historycznej”, opisuje aktualną politykę Kremla jako „koniunkcję nanotechnologii przyszłości z mnemotechnologią przeszłości”. Jego zdaniem przeważającym mechanizmem regulacji przestrzeni symbolicznej w Rosji jest monopolizacja zasobów kulturowych i przeciwdziałanie jakimkolwiek próbom podważenia hegemonicznego położenia. Takie traktowanie przeszłości powoduje, że niewyczerpane złoża stają się dobrem ograniczonym i nieodnawialnym, a spór o przeszłość przekształca się w grę o sumie zerowej, w której zwycięstwo jednej strony musi niechybnie oznaczać klęskę drugiej. $W$ tych

\footnotetext{
${ }^{5}$ J. Le Goff, Historia i pamięć, przeł. A. Gronowska, J. Stryjczyk, Warszawa 2007, s. 99.

${ }^{6}$ P. Connerton, Jak społeczeństwa pamiętaja, przeł. M. Napiórkowski, Warszawa 2012, s. 49.
} 
warunkach polityka historyczna brutalizuje się - i wszystko to w celach modernizacyjnych ${ }^{7}$. Nie zamierzam polemizować $w$ tym miejscu z istotą diagnozy Kalinina, choć materiał zaprezentowany poniżej każe wątpić w umiejętność wykorzystywania przez rosyjskie władze całego dostępnego instrumentarium historycznego ${ }^{8}$.

Jakkolwiek artykuł traktuje o politycznym wymiarze jubileuszów państwowości rosyjskiej, plasuje się dość odlegle od perspektywy badawczej redukującej studia nad Rosją do sfery polityki oderwanej od kultury. Nadmierna polityzacja spojrzenia na Rosję uniemożliwia dostrzeżenie uniwersalnego charakteru występujących tam zjawisk. Refleksja nad trudnymi kolejami rosyjskich losów potwierdza intuicję polskiego kulturoznawcy, który przypisywał pamięci zbiorowej kluczową rolę w procesie kształtowania się tożsamości indywidualnych i zbiorowych. Czerpiąc $\mathrm{z}$ dorobku pioniera badań nad pamięcią, Pierre’a Nory, uczony upatruje w rosnącym zainteresowaniu przeszłością próbę zrekompensowania ubytków powstałych na skutek fragmentaryzacji pamięci, spowodowanej dynamiką zmiany, jaka towarzyszy społeczeństwu nowoczesnemu i ponowoczesnemu'. Kulturowe nachylenie analizy pozwala ostudzić ekscytację polityczną stroną przedsięwzięć służących ingerencji w tożsamość, gdyż uświadamia praktyczne trudności skutecznego narzucenia czegokolwiek ludzkiej pamięci. Trudności te oddaje brak automatycznego przełożenia nowopowstałego wizualnego znaku jakiejś przestrzeni na pamięć; siła oddziaływania przestrzeni symbolicznej jest ograniczona ${ }^{10}$.

\section{Ideowa oprawa jubileuszu 1000-lecia państwowości rosyjskiej - refleksja liberalna}

W niniejszym artykule nie stawiam sobie zadań komparatystycznych: nie leży w moich zamiarach konfrontowanie motywów działania organizatorów obchodów ani porównywanie przebiegu uroczystości. W przypadku XIX-wiecznego jubileuszu byłoby to daremne, gdyż został on wszechstronnie opisany w literaturze przedmiotu; obok klasycznego już studium semiotyki władzy Richarda Wortmana,

7 I. Kalinin, The Struggle for History: The Past as a Limited Resource, w: Memory and Theory in Eastern Europe, red. U. Blacker, A. Etkind, J. Fedor, New York 2013, s. 256, 260-261.

8 Teza petersburskiego badacza wydaje mi się godna rozważenia w szerszym kontekście: „jak zmiany makroinstytucjonalnych konfiguracji i polityczno-legitymizacyjnych dyskursów, które nastąpiły w toku postsocjalistycznej demokratyzacji, warunkują twórczą i krytyczną komemoracyjną recepcję konceptów narodu i modernizacji” - А. Лангеноль, Общественная память после смены строя: сходства и различия между практиками памяти в посткоммунистических и постколониальных странах, „Ab Imperio” 1 (2004), s. 380.

9 B. Korzeniewski, Wprowadzenie. Przemiany pamięci społecznej z perspektywy teorii kultury polskie i niemieckie przestrzenie pamięci, w: Przemiany pamięci społecznej a teoria kultury, red. B. Korzeniewski, Poznań 2007, s. 9.

10 С.А. Еремеева, Монументальные практики коммеморации в России ХІХ и начала XX века, w: Образы времени и исторические представления: Россия - Восток - Запад, ред. Л.П. Репина, Москва 2010, s. 906, 910. 
który poświęcił mu jeden podrozdział ${ }^{11}$, mamy do dyspozycji mistrzowski szkic rosyjskiej badaczki - dogłębną i wszechstronną analizę ${ }^{12}$. Wymienieni autorzy poddają wiwisekcji intencje elity rządzącej, wpisując je w dyskurs legitymizacyjny ${ }^{13}$. Z mojego punktu widzenia wartość obu opracowań polega na tym, że w sposób nie budzący wątpliwości ukazują one zakotwiczenie politycznego wymiaru jubileuszu w (auto)świadomości historycznej, a nawet kulturowej obserwatorów-uczestników święta. Jubileusz tysiąclecia - zgodnie dowodzą historycy - był autentycznym przeżyciem rosyjskich poddanych imperium (w jakim stopniu poddanych rosyjskiego imperium w ogóle, to już inna sprawa, wymagająca szczegółowych badań). Konstatacja ta uprawnia uznanie $1862 \mathrm{r}$. za jeden $\mathrm{z}$ ważnych węzłów pamięci potomków tamtych zdarzeń, żyjących w XXI w. i powołujących się na to dziedzictwo ${ }^{14}$.

Jeśli rezygnuję z omawiania ceremonialnego aspektu jubileuszu tysiąclecia, to czynię to w przeświadczeniu, że ponowne eksploatowanie tych samych źródeł nie wniesie niczego nowego do ustaleń wspomnianych wyżej uczonych. Zamiast powielać wysiłek poprzedników, zdecydowałem się jedynie zaprezentować wybór okazjonalnej publicystyki, drukowanej na łamach najważniejszych liberalnych pism. Decyzję tę dyktuje ważka okoliczność: do liberalnych wartości tamtego czasu niejednokrotnie (o czym jeszcze będzie mowa) nawiązywał inicjator jubileuszu 1150-lecia - prezydent Dymitr Miedwiediew. Jak dotąd wykorzystany przeze mnie materiał prasowy nie był badany pod kątem wyekstrahowania zeń głównych cech liberalnego programu politycznego ${ }^{15}$. Przedstawiam trzy teksty pełniące funkcje manifestów ideowych, opublikowane w opiniotwórczych gazetach: dzienniku „Wiadomości Sankt-Petersburskie” („Санкт-Петербургские ведомости”),

11 Р.С. Уортман, Сиенарии власти. Мифы и иеремонии русской монархии, t. 2: От Александра II до отречения Николая II, Москва 2004, s. 117-131.

12 О. Майорова, Бессмертный Рюрик: Празднование тысячелетия России в 1862 г., «Новое литературное обозрение» 43 (2000), s. 137-165. Korzystam z elektronicznej wersji artykułu - http://magazines.russ.ru/nlo/2000/43/s6.html (dostęp: 3.09.2014).

13 Przedstawione przez nich omówienia wydają się przekonujące, choć należy mieć na uwadze, że nie wszyscy uczestnicy wydarzeń przydawali im tak duże znaczenie - przykładem spisana wiele lat później relacja ówczesnego ministra wojny, Dymitra Milutina - Д.А. Милютин, Воспоминания. 1860-1862, ред. Л.Г. Захарова, Москва 1999, s. 386-391.

${ }^{14}$ Niczego nie zmienia tu - dodam od razu - ewentualny zarzut, wedle którego na inspirowanej przez Aleksandra II i jego otoczenie wizji zaprezentowanej przed 150 laty cieniem położyła się mitologizacja przeszłości. Jak bowiem zauważa rosyjski badacz, mity historyczne wciąż pozostają ważną formą świadomości społecznej, bo też są one nieodłączną częścią tradycji kulturowych - С.В. Конорев, Исторический миф в современном российском обществе: происхождение и социокультурная роль, w: Кризисы переломных эпох в исторической памяти, ред. Л.П. Репина, Москва 2012, s. 332-333.

15 Całościową (jeśli wierzyć zapowiedzi autoreferatu pracy kandydackiej) panoramę prasową jubileuszu tysiąclecia państwowości rosyjskiej zaprezentował А.И. Буслаев, Имперские юбилеи тысячелетие России (1862 год) и девятисотлетие крещения Руси (1888 год): организация, символика, восприятие обществом, rozprawa doktorska, Москва 2010. Autor rozprawy nie ustrukturyzował analizowanych tekstów ze względu na ich ideowe nachylenie. Praca zawiera najrozleglejszą w literaturze przedmiotu bibliografię źródłową dotyczącą interesującej mnie tematyki. 
tygodniku „Kronika Współczesna” („Современная летопись”), miesięczniku „Zapiski z Kraju Rodzinnego” („Отечественные записки”). „Kronika” to organ prasowy Michała Katkowa (1818-1887), liberała-okcydentalisty, który po upływie kilku lat przejdzie na pozycje konserwatywne, by w latach 80. XIX w. jako redaktor „Wiadomości Moskiewskich” („Московские ведомости”) stać się głównym ideologiem polityki Aleksandra III. Z kolei redaktorem „Zapisków” i dzierżawionych od Cesarskiej Akademii Nauk „Wiadomości” był konsekwentnie promujący wartości liberalne Andrzej Krajewski (1810-1889), jeden z najbardziej wpływowych stołecznych wydawców, przyszły właściciel najpoczytniejszego w latach 70 . XIX w. dziennika „Głos” („Голос”).

$\mathrm{Na}$ ówczesnej liberalnej publicystyce bardzo wyraźnie odciskały się próby nadania sensu tysiącletniemu istnieniu państwa rosyjskiego. Nie znajdziemy tam autoafirmacji, przeciwnie: widoczny jest samokrytycyzm. Felietonista „Wiadomości Sankt-Petersburskich" zauważał, że bezprecedensowa ekspansja terytorialna Imperium Rosyjskiego nie stanowi autotelicznego celu. Owszem, w ciągu dziesięciu stuleci dokonał się spektakularny rozrost państwa, którego kolebką był niewielki obszar nieopodal jeziora Ilmień. Władztwo Rosji sięga Karpat na zachodzie, pustyń lodowych Ameryki Północnej na wschodzie, bieguna polarnego na północy i suchych stepów Azji Środkowej na południu. Rosjanie „zmusili do szanowania swojej siły" zarówno nieokrzesanych Amerykanów, jak i kulturalnych Paryżan z satysfakcją konstatował autor. Wnet jednak dodawał, iż nie odgadli oni jeszcze rzeczywistego celu swoich dążeń, choć czują go instynktownie ${ }^{16}$.

Zdaniem publicysty stołecznego dziennika początek drugiego tysiąclecia historii Rosji wyznacza nowy etap budowy państwowości. Wszelako każda konstrukcja musi wspierać się na solidnych podstawach. Szczęśliwie fundament pod wyzwania nowej epoki jest już założony: Manifest 19 lutego $1861 \mathrm{r}$. nie pozostawia wątpliwości, że cała uwaga winna zostać skierowana na lud, czyli na chłopstwo. Autor felietonu z wyraźną satysfakcją odnotowywał, iż w Imperium Rosyjskim wielka przemiana symbolizowana przez zwolnienie chłopów z poddaństwa dokonała się z woli rządzących. Inaczej było na Zachodzie, gdzie poprzedziły ją społeczne wstrząsy, krwawe konflikty klasowe, rewolucje. Liberalny komentator nie poprzestawał na tej pochwale władz, nie zawahał się wkroczyć na grząski grunt politycznej futurystyki. Jeśli Rosja ma dokonać przewrotu światowego dywagował - to nie będzie on polegać na opanowaniu kolejnych połaci planety, lecz na upowszechnieniu w praktyce utopii, o których marzą zachodni filozofowie, a które urzeczywistniają się w rosyjskim ludzie (narodzie). Wiara w misję swojej ojczyzny uprawomocniała opinię, że naznaczona podbojami przeszłość Imperium Rosyjskiego nie była wcale bezpłodna, a jedynie przygotowywała grunt dla wspaniałej przyszłości ${ }^{17}$.

\footnotetext{
16 Д., 862-1862, „Санкт-петербургские ведомости” 1 (3.01.1862), s. 1.

17 Ibidem, s. 1-2.
} 
Widoczne w przytoczonym rozumowaniu przeświadczenie o tym, że Rosja wkracza w nową erę, nie było czymś wyjątkowym. Ten punkt widzenia najdobitniej został wyartykułowany w „Kronice Współczesnej”. Poniższy ekstrakt z rocznicowej publicystyki daje dobre wyobrażenie o sposobie myślenia liberałów skupionych w redakcji tego pisma. Komentator katkowowskiego czasopisma wykluczał koincydencję zniesienia poddaństwa i wielkiego jubileuszu. Według niego jednoczesność obu wydarzeń jest wyrazem woli opatrzności. Manifest 19 lutego to finałowy akt mijającego tysiąclecia, budowy „wszechrosyjskiego państwa”, naznaczonej ogromnym wysiłkiem i przelaną krwią. Los historyczny dokonał rozstrzygnięcia: uczynienie reprezentantów wszystkich stanów ludźmi wolnymi kończy rozliczenia minionych stuleci, zamyka przeszłość. Odtąd zaczyna się już nowe życie, a także inne trudy i wyzwania ${ }^{18}$.

Istota liberalnej argumentacji „Kroniki Współczesnej” zawiera się w udatnym połączeniu wątków imperialnych i modernizacyjnych. Według autora omawianego tekstu paradoksalnie potęga Rosji sprzyja rozwojowi indywidualnemu i społecznemu jej poddanych. Tysiącletni wysiłek sprawił, że państwo rosyjskie wspiera się na trwałych podstawach i w nowej epoce nie musi już koncentrować się na przetrwaniu: niewzruszoność fundamentów pozwala skupiać się na życiu narodowym. Nareszcie państwo może realizować swoje przeznaczenie: usuwanie przeszkód dla swobodnego rozwoju poddanych jest rekompensatą za poniesione wcześniej ofiary. Co więcej, wykorzystanie inicjatywności i energii ludzi jest wręcz obiektywną koniecznością rozwoju historycznego. W opinii autora próba obejścia tej drogi uniemożliwiłaby Rosji już nie tylko kroczenie naprzód, ale nawet utrzymanie równowagi. Odmówienie społeczeństwu prawa do autonomii godziłoby w imperium: podważałoby jego jedność, osłabiałoby jego polityczne znaczenie. Występuje tu - wyjaśniał publicysta, używając innego terminu - sprzężenie zwrotne: siła państwa czerpie z życia narodowego i jest wprost proporcjonalna do wkładu w rozwój tegoż i poziomu zapewnionych mu warunków istnienia. Inaczej mówiąc, podporą imperialnego istnienia jest siła moralna, której żywotność zależy od stopnia swobody funkcjonowania jej nosicieli ${ }^{19}$.

Zależność opisana przez współpracownika redakcji czasopisma Katkowa miała dla ówczesnych rosyjskich liberałów charakter aksjomatyczny. Warto ustalić, jak przy pomocy odwołań do historii ojczystej uzasadniali oni takie stanowisko. Rzecz to tym ważniejsza, że pozwala zorientować się, czym dla pokolenia epoki wielkich reform było dziedzictwo Rusi niesamowładnej. Spośród tekstów poświęconych tym zagadnieniom bodaj najbardziej wyczerpująca analiza ukazała się drukiem na łamach „Zapisków z Kraju Rodzinnego”. Jej autorem był Mikołaj Kostomarow (1817-1885), humanista różnych specjalności, poeta, działacz

\footnotetext{
18 Праздник тысячелетия России в Новгороде, „Современная летопись Русского вестника” 37 (09.1862), s. 12.

19 Ibidem, s. 13.
} 
społeczny o inklinacjach ukrainofilskich, wówczas etatowy wykładowca i profesor historii Uniwersytetu Petersburskiego. W tym miejscu artykuł Kostomarowa interesuje mnie jedynie jako odbicie liberalnego punktu widzenia na dzieje Rosji, toteż ani nie przeprowadzam wnikliwej analizy zawartych tam twierdzeń, ani nie konfrontuję ich z innymi nurtami ideowymi ówczesnej rosyjskiej historiografii.

Kostomarow interesował się antynomią dwu zasad ustrojowych: jedynowładztwa i księstw dzielnicowych $\mathrm{z}$ wiecem jako centralnym organem władzy. Uważał on, że walka tych skrajnie różnych form życia politycznego była osią dziejów państwa ruskiego, a jej rozstrzygnięcie na korzyść tej pierwszej nie czyni bynajmniej bezwartościową tej drugiej. Wynika to stąd, że rosyjski charakter kształtował się pod wpływem ich obu. Zdaniem historyka Nowogród Wielki nie stanowił wyjątku na tle innych organizmów średniowiecznej Rusi, a instytucja wiecu to typowy dla tamtych czasów wyraz autonomii poszczególnych ziem. W pojęciu Nowogrodzian dążenie do utrzymania niezawisłości nie stało w sprzeczności z potrzebą zachowania ścisłych związków z pozostałymi bytami politycznymi wschodniej Słowiańszczyzny czy jedności terytorialnej ziem ruskich. O niepowodzeniu modelu federacyjnego przesądziła niewola tatarsko-mongolska. Wprawdzie nie dotknęła ona bezpośrednio Nowogrodu, ale ośrodek ten stał się tylko kadłubem mocarstwa. Tymczasem ludowładztwo, łączące wymogi prawa rodowego z respektowaniem wolności osobistej, mogło przyjąć się tylko na całym ruskim obszarze, nigdy zaś na jego części. Co więcej, rozprzestrzenianie się i pogłębianie wolności zależą od „ducha, poziomu rozwoju umysłowego, od wyobrażeń o moralnym i społecznym obowiązku", a warunki po temu ze względu na obiektywne okoliczności przedstawiały się niekorzystnie. Optymistyczna wymowa tekstu Kostomarowa znajdowała oparcie w przeświadczeniu, iż po kilkuset latach od podporządkowania Nowogrodu książętom moskiewskim (czasy Iwana III) państwowość i narodowość wreszcie pogodziły się ze sobą. Wielowiekowa walka jedynowładztwa i udzielności dobiegła końca. Potędze państwa nic już nie zagrozi, aktywność poddanych w żaden sposób jej nie zaszkodzi. Historia Rosji zaczyna się niejako na nowo - konkludował uczony publicysta ${ }^{20}$.

Trzy omówione wyżej interpretacje nie zostały wypowiedziane unisono. Trudno wszakże oprzeć się wrażeniu, że łączą je ważne cechy wspólne - i to właśnie one uprawniają traktowanie przywołanej publicystyki jako miarodajnego źródła wiedzy o nastrojach liberalnych kręgów u zarania epoki wielkich reform. Ówcześni liberałowie rosyjscy postrzegali jubileuszowy rok 1862 r. jako „wododział” separujący dwie ery: erę hipertrofii państwa w życiu społecznym i erę równoprawnej koegzystencji władzy i poddanych. Kres pierwszego tysiąclecia wyznaczyło zwolnienie chłopów z poddaństwa - symboliczne i faktyczne postawienie wolności na piedestał. W mniemaniu cytowanych autorów (i stojących za nimi środowisk) poszerzanie zakresu wolności jednostek jest warunkiem koniecznym wzrostu imperialnej

${ }^{20}$ Н.И. Костомаров, О значении Великого Новгорода в русской истории, „Отечественные записки” 140 (1862), styczeń, s. 84, 88, 92-93, 95-96, 99, 102, 104. 
potęgi Rosji. Więcej jeszcze, dalsze sekwestrowanie wolności godziłoby w Imperium Rosyjskie. Ta optymistyczna wizja nadchodzących czasów czerpała z uznania, że obiektywny rozwój stosunków społeczno-politycznych pozwolił rozwijać się bezkonfliktowo dwóm równorzędnym wartościom: państwowości i narodowości. Odtąd pomyślność jednej nie realizowała się kosztem drugiej, bo też ich cel był wspólny - dowartościowanie warstw nie cieszących się dotąd pełnią praw cywilnych. Oczywiście, w takim rozłożeniu publicystycznych akcentów sporo było szlachetnej naiwności, która swój najpełniejszy wyraz znalazła chyba w zacytowanej przez jednego $z$ autorów Wergiliańskiej frazie „iam nova progenies caelo demittitur alto"21. Niepodobna wszakże kwestionować autentyczności i szczerości liberalnych komentatorów, gdy twierdzili oni, że oto kształtuje się całkowicie nowy porządek. Podobne opinie ukazują szczerość dążeń do zmiany status quo.

Przypomnienie w niniejszym artykule publicystycznych głosów sprzed półtora stulecia nie jest sprawą przypadku: liberalne periodyki żyrowały reformatorskie przedsięwzięcia inicjowane przez Aleksandra II i tzw. liberalnych biurokratów. Wiedza o tym, co zajmowało ówczesne władze i opinię publiczną, oraz jak konstruowano argumentację na rzecz przemian, jest naturalnym punktem odniesienia dla dyskursu modernizacyjnego Dymitra Miedwiediewa, sprawującego najwyższy urząd w Rosji w latach 2008-2012. Przeświadczenie prezydenta Federacji Rosyjskiej o powinowactwie „epoki wielkich reform” i jego rządów aż nadto wyraźnie wybrzmiało w przemówieniu programowym z 3 marca 2011 r., wygłoszonym podczas konferencji „Wielkie reformy i modernizacja Rosji”22. Zważywszy na tę okoliczność, zapomniana publicystyka jubileuszowa 1862 r. przestaje być tylko antykwarycznym zabytkiem. Jej lektura (podobnie jak znajomość publicystyki lat 60. i 70. XIX w.) daje podstawy do zakwestionowania rozpowszechnionych i nazbyt uproszczonych sądów o rosyjskiej modernizacji jako przedsięwzięciu wszczynanym wyłącznie w celu umocnienia pozycji rządzących ${ }^{23}$. Co jeszcze ważniejsze, podważa

${ }^{21}$ Jest to ósmy wers tajemniczej IV eklogi Wergilego. Uchwyceniu sensu przysłuży się podanie poprzedzających go wersów: „Ultima Cumaei venit iam carminis aetas; / Magnus ab integro saeclorum nascitur ordo. / iam redit et Virgo, redeunt Saturnia regna / iam nova progenies caelo demittitur alto”. Polska tłumaczka przełożyła ten fragment Bukolik następująco: „Oto ostatni się czas kumejskiej [Kyme - miasto, gdzie przebywała wieszczka Sybilla] pieśni pojawił, / Oto na nowo się wieków odradza wielki porządek, / Już Dziewica [tj. Sprawiedliwość] powraca, powraca królestwo Saturna, / Nowy potomek [tj. nowy wybawiciel] z niebios wysokich na padół zstępuje”, Wergiliusz, Bukoliki i georgiki (wybór), przeł. i oprac. Z. Abramowiczówna, Wrocław 1953, s. 19.

22 Zob. analizę tego przemówienia w podrozdziale „Współczesne interpretacje i konteksty epoki cara-wyzwoliciela" w mojej nieopublikowanej pracy doktorskiej Reformy a zmiana społeczna $w$ Rosji Aleksandra II. Dymitr Milutin i gazeta "Gołos” w sporach o ksztalt oświaty i armii, UJ, Kraków 2015.

${ }^{23}$ Tak m.in. J. Potulski, Współczesny rosyjski dyskurs modernizacyjny, w: Fenomen Rosji. Pamięć przeszłości i perspektywy rozwoju, cz. 2: Kontekst polityczny i gospodarczy, red. J. Diec, A. Jach, Kraków 2014, s. 127; M. Broda, „Rosyjska idea” i problemy modernizacyjne Rosji, w: Bariery modernizacji Rosji, red. S. Bieleń, A. Skrzypek, Warszawa 2014, s. 71. 
ona prostolinijne przeciwstawienie imperialnego i liberalnego modelu rosyjskiej modernizacji ${ }^{24}$. W rzeczywistości niektóre nurty przedrewolucyjnego liberalizmu wspierały projekty imperialne, a nawet więcej: imperialna Rosja wydawała się im skuteczną promotorką ideałów liberalnych.

\section{Obchody 1150-lecia państwowości rosyjskiej w Nowogrodzie Wielkim (2012)}

\section{Intencje pomysłodawców - wizja prezydenta Dmitrija Miedwiediewa}

$\mathrm{O}$,jubileuszowych” intencjach prezydenta Dymitra Miedwiediewa można wnosić z udostępnionych opinii publicznej materiałów, przede wszystkim zapisów video z zarejestrowanymi spotkaniami głowy państwa z przedstawicielami gremiów odpowiedzialnych (pod względem merytorycznym i logistycznym) za przygotowanie uroczystości. Przywódca Rosji najpierw wysłuchał opinii zaproszonych kilkunastu historyków, reprezentujących różne ośrodki akademickie oraz Rosyjską Akademię Nauk, następnie odbył naradę z członkami prezydiów dwu prezydenckich rad: Rady Kultury i Sztuki, oraz Rady Nauki, Technologii i Edukacji (obecnie: Nauki i Edukacji). Oba posiedzenia odbyły się we Włodzimierzu nad Klaźmą 22 lipca 2011 r. ${ }^{25}$ Wybór miejsca nie był przypadkowy: władcy księstwa włodzimiersko-suzdalskiego, obejmującego północno-wschodnią część Rusi, czyli terytoria kadłubowe Rosji, skutecznie walczyli o prymat polityczny na ziemiach ruskich, co znalazło swój wyraz nie tylko w używaniu przez nich tytułu wielkoksiążęcego, lecz także w przeniesieniu do stolicy ich państwa siedziby metropolity kijowskiego. Wprawdzie to książęta moskiewscy dokonali zjednoczenia ziem ruskich, ale w powszechnej świadomości należący do tzw. Złotego Pierścienia Włodzimierz pozostaje protoplastą Moskwy, być może za sprawą metod postępowania Andrzeja Bogolubskiego (druga połowa XII w.), który przyjął tytuł wielkiego księcia i właśnie tam przeniósł stolicę z Kijowa. Niezależnie od źródeł takich skojarzeń wybór włodzimierskiego kompleksu muzealnego na miejsce prezydenckich konsultacji, przydawało znaczenia tym roboczym posiedzeniom i sprawiało, że nie stawały się one kolejnymi, rutynowymi zebraniami, wypełniającymi kalendarz przywódcy Rosji.

Uczestnicy obu narad wypowiadali się w różnych sprawach, a zagadnienia koncepcyjno-organizacyjne planowanych obchodów 1150-lecia, choć formalnie pierwszoplanowe, ustąpiły miejsca wymianie poglądów na kwestie natury ogólnej,

${ }^{24}$ Tak S. Bieleń, Szanse modernizacji na tle osobliwości rosyjskiej polityki, w: Bariery..., s. 217-218.

${ }^{25}$ Zapisy video wraz ze stenogramami udostępniła służba prasowa Kremla. Ponieważ opinie prezydenta były względem siebie komplementarne (w dużym stopniu pokrywały się), omawiam je zbiorczo. Zob. Встреча с учёными-историками, http://www.kremlin.ru/news/12073 (dostęp: 3.09.2014); Заседание по вопросу подготовки к празднованию 1150-летия зарождения российской государственности, http://www.kremlin.ru/transcripts/12075 (dostęp: 3.09.2014). 
dotyczące perspektyw poprawy kondycji nauki historycznej, świadomości historycznej Rosjan oraz sposobów jej kształtowania, i wreszcie relacji między historią a polityką. Referowanie wszystkich opinii przekraczałoby ramy niniejszego artykułu, nierównie ważniejsze dla poruszonej tu tematyki wydają się poglądy gospodarza spotkania. Zacząć wypada od prezydenckiej motywacji odwoływania się do symbolicznych narodzin Rusi. Miedwiediew dzielił się z zebranymi wątpliwościami towarzyszącymi podpisaniu dekretu o świętowaniu w 2012 r. początków rosyjskiej państwowości; ponoć wahał się kilka miesięcy, czy to uczynić. Obawiał się stworzenia precedensu (?!) rozstrzygania przez państwo o słuszności jednej z naukowych teorii, wciąż jeszcze kontestowanej przez niektórych badaczy. Wszak ogłoszenie dekretu jest równoznaczne z podniesieniem teorii normańskiej do rangi aktu normatywnego, ze wszystkimi prawnymi konsekwencjami tego faktu. Ostatecznie jednak zdecydował się na ten krok, uznając, że jego pozytywne aspekty przeważają nad negatywnymi, a ryzyko błędu niweluje zgoda większości uczonych co do prawdziwości historycznej interpretacji zachowanych źródeł kultury materialnej i duchowej.

Co miał na myśli prezydent Rosji, mówiąc o dodatnich stronach oficjalnego świętowania jubileuszu powstania Rusi? Odpowiedź na to pytanie zawiera się w lakonicznym tekście dekretu z 3 marca 2011 r. obwieszczającym, że celem planowanych obchodów jest „dalsza konsolidacja społeczeństwa rosyjskiego”26. W świetle tego stwierdzenia praktyczny wymiar planowanej celebracji staje się celem pierwszorzędnym i skłania do analizy pozostałej części wypowiedzi Miedwiediewa, która traktuje o fundamentach państwowości, co ma niebagatelne znaczenie dla zrozumienia sposobu myślenia nie tyle o minionych stuleciach historii Rosji, ile przede wszystkim o czasach obecnych. Wcześniej jednak trzeba wskazać źródła inspiracji, z których czerpał przywódca Federacji Rosyjskiej. Pragnąc uczcić prapoczątki rządzonego przez siebie kraju, nawiązywał on bezpośrednio do Aleksandra II i podkreślał, że w ciągu kolejnych stu pięćdziesięciu lat po carze-wyzwolicielu nikt już nie zdecydował się wskrzesić tej inicjatywy. Miedwiediew, który darzy epokę wielkich reform estymą, snuł paralelę między nią a współczesną rzeczywistością, przypisując promotorowi XIX-wiecznych przemian intencję zbliżenia władzy i narodu. Rosyjski prezydent, roszczący sobie ambicje zmodernizowania państwa, porównywał złożoność ówczesnej i dzisiejszej sytuacji, tym samym znajdując w dziejach ojczystych argument na rzecz nieodzowności konsolidacji, zwłaszcza konsolidacji narodowej.

Wolno zakładać, że opinie Miedwiediewa wybrzmiałe 22 lipca 2011 r. awizowały tezy przyszłego wystąpienia jubileuszowego. Warto w tym miejscu wspomnieć o dwóch wątkach. Po pierwsze, prezydent bardzo krytycznie odniósł się do spotykanych w publicystyce ujęć historii ojczystej w duchu samoupokorzenia.

26 Указ Президента РФ „О праздновании 1150-летия зарождения российской государственности” 3 марта 2011 года N 267, http://old.rs.gov.ru/sites/rs.gov.ru/files/1_-_Ukaz_Prezidenta_ RF_03_03_2011.pdf (dostęp: 3.09.2014). 
Miał na myśli niedopuszczalność interpretacji dziejów Rosji w kategoriach państwa, które zarówno swoje powstanie, jak i dalszy rozwój zawdzięcza wyłącznie kontaktom z kulturą zachodnioeuropejską, gdyż samodzielnie nie potrafiło niczego stworzyć ani osiągnąć. Argumentacja Miedwiediewa jest interesująca, ponieważ nie odwołuje się do dumy narodowej czy antyzachodnich resentymentów, za to akcentuje wysoki poziom kultury prawnej Rusi. Od samego początku - twierdził - Ruś kształtowała się jako państwo prawne: ugruntowane zasady postępowania normowały relacje międzyludzkie i podtrzymywały ład społeczny; wpływały nie tylko na to, jak ludzie żyją, ale i na to, jakie wartości wyznają. Prawo wiązano ściśle ze sprawiedliwością, która pozwalała rozstrzygać konflikty w zgodzie z prawdą. Ważną rolę w egzekwowaniu sprawiedliwości wypełniała władza - to ona dbała o rozwój państwa, pilnowała interesów poddanych, pielęgnowała zróżnicowane tradycje ludności rozległego terytorium. Zdaniem prezydenta Federacji Rosyjskiej błędne i szkodliwe są koncepcje negatywistyczne, przejawiające się w kwestionowaniu tezy o prawie jako ważnym czynniku spajającym państwo ruskie. Ich zaaprobowanie odbierałoby bowiem zasadność dzisiejszym ambicjom podążania drogą demokratyczną i cofałoby Rosję o całe stulecie.

Po drugie, Miedwiediew wskazywał na polietniczność jako konstantę rozwoju Rosji od pierwszych chwil jej istnienia. W jego opinii dzieje państwowości ruskiej zostały podporządkowane logice jednoczenia, gdyż rozdrobnienie traktowano jako wyznacznik słabości. Inaczej było z różnorodnością kulturową i religijną, których nie postrzegano jako potencjalne zagrożenie. Przez ponad jedenaście stuleci Rosja była odrębną „wielonarodową cywilizacją, dysponującą unikalnym potencjałem etnokulturowym", należy więc uczynić wszystko, by właściwe Rosjanom tolerancyjność i wzajemny szacunek nieodmiennie pozostawały normą dla społeczeństwa. Prezydent utrzymywał, że najmocniejszym dowodem na powszechność takiej postawy jest sama długowieczność państwa. Gdyby było inaczej, gdyby nie istniała „siła jednocząca różnych ludzi”, to tak wielka wspólnota nie przetrwałaby, dzieląc los wielu tworów, które bezpowrotnie znikły. Jakkolwiek projekcja Miedwiediewa idealizowała stosunki panujące w państwie rosyjskim, przemilczając tendencje szowinistyczne żywiołu ruskiego, to przecież przyznał on, iż polietniczność stanowi i będzie stanowić w przyszłości jedno ze źródeł problemów, z jakimi zmagają się rządzący Rosją. Jeśli jednak kraj ma przetrwać, muszą oni z jednej strony zachować owo zróżnicowanie, z drugiej zaś - znaleźć rozwiązanie sprzeczności, które są nieodłącznym elementem złożonych organizmów.

Warto zwrócić uwagę na jeszcze jeden moment w wypowiedziach Miedwiediewa. Prezydent expressis verbis oświadczył, że rozwój państwa jest niemożliwy bez „punktów consensusu". Zgodne stanowisko co do najważniejszych wydarzeń z przeszłości to, według niego, „magistralna droga”, którą podążają naród, państwo, a nawet ludzkość. Oddanie zajmowanych pozycji może okazać się brzemienne w skutki, toteż w kluczowych sprawach (np. wielka wojna ojczyźniana) zgoda $\mathrm{w}$ łonie społeczeństwa i establishmentu pozwala uniknąć zmierzania $\mathrm{w}$ niepo- 
żądanym kierunku. Mówca zastrzegł, iż ma na myśli tylko sferę edukacji: młodzi Rosjanie winni wynosić ze szkoły wiedzę o tym, jak kształtował się ich kraj; natomiast $\mathrm{w}$ nauce dopuszczalne są rozmaite interpretacje tych samych zdarzeń. Sformułowana $\mathrm{w}$ języku technokratycznym wypowiedź dowartościowuje znaczenie polityki historycznej, zapowiadając konsekwentniejsze niż dotąd wykorzystanie narzędzi do jej prowadzenia. Nie była to tylko pusta deklaracja intencji, gdyż rosyjskie władze podjęły wysiłek urzeczywistnienia postulatu jednolitego ukierunkowania szkolnego nauczania ${ }^{27}$. W tym kontekście nie brzmiały przekonująco zapewnienia Miedwiediewa, że treść ogólnonarodowego porozumienia wcale nie musi być narzucana przez czynniki administracyjne. Omawiając półformalne wystąpienia prezydenta Rosji, trudno też przemilczeć typową dla sposobu myślenia rosyjskich elit politycznych skłonność do opisywania zjawisk w kategoriach uniwersalistycznych. Chyba tak należy interpretować napomknienie o zbiorowości ogólnoludzkiej, sugerujące, że służącego spoistości wspólnoty rosyjskiej consensusu $\mathrm{w}$ istocie potrzebują wszyscy.

\section{Plan i przebieg uroczystości}

Wyobrażenie o tym, że obchody 1150-lecia początków rosyjskiej państwowości przybiorą postać ogólnonarodowego święta, rozwiało rządowe rozporządzenie z 6 lutego 2012 r., zatwierdzające listę planowanych 63 przedsięwzięćc ${ }^{28}$. Wynikało zeń niezbicie, że władze nie przewidują żadnych centralnych uroczystości. Fundusz 450 milionów rubli ( $80 \%$ tej kwoty pochodziło $\mathrm{z}$ budżetu centralnego, $10 \%$ - z budżetu poszczególnych podmiotów administracyjnych, reszta $\mathrm{z}$ innych źródeł, w tym od sponsorów) podzielono na sfinansowanie kilku kategorii wydatków. Lwią część środków (380 mln rubli) przeznaczono na „memorializację miejsc pamięci”, czyli odrestaurowanie zaniedbanych obiektów o randze historycznej, zwłaszcza kremlów i budowli sakralnych. Nad pracami realizowanymi w Starej Ładodze, Nowogrodzie Wielkim, Wołogdzie, Biełoziersku, Rostowie Wielkim, Pskowie, Kostromie, Starej Rusie kuratelę sprawowało ministerstwo kultury. Stosunkowo nieduże kwoty przeznaczono na organizację pięciu konferencji naukowych, przygotowanie trzech ekspozycji muzealnych, wydanie siedmiu publikacji naukowych i popularnych, i wreszcie stworzenie internetowego projektu-wystawy. Dość niewielkie sumy miała pochłonąć organizacja festiwalów, konkursów, zlotów, parad i rekonstrukcji historycznych, których tematyka była niekiedy bardzo luźno związana z głównymi uroczystościami. Znamienne wydaje się to, że za najważniejsze przedsięwzięcia

27 Zob. A. Каспшыцка, Реформа системы образования в России и формирование исторической памяти граждан, w: Fenomen Rosji..., s. 109-116.

28 Распоряжение Правительства РФ от 06.02.2012 N 153-р „О плане основных мероприятий по подготовке и проведению празднования 1150-летия зарождения российской государственности", www.consultant.ru/document/cons_doc_EXP_524549 (dostęp: 3.09.2014). 
uznano: nakręcenie niefabularnego filmu poświęconego 1150-leciu państwowości (ledwie 2,6 mln rubli), organizację konferencji „Północny-zachód - kolebka rosyjskiej państwowości”, przeprowadzenie w Jałcie (Ukraina) kolejnego kongresu lingwistycznego, oraz nakręcenie serialu dokumentalnego poświęconego roli, jaką poszczególne narody odegrały w powstaniu państwa. Jak widać, władze postanowiły rozwijać równolegle wiele projektów skierowanych do różnych środowisk, przy czym żadna z tych imprez nie miała się stać punktem odniesienia dla pozostałych.

W tym stanie rzeczy ciężar stworzenia programu uroczystości jubileuszowych zaplanowanych w Nowogrodzie Wielkim spoczął na władzach lokalnych. Trzydniowe obchody rozpoczynały się 21 września, w 150. rocznicę odsłonięcia przez Aleksandra II pomnika Tysiąclecie Rusi (odpowiednikiem 8 września 1862 r. jest dziś 21 września, albowiem w chwili obecnej różnica między używanym w przedrewolucyjnej Rosji kalendarzem juliańskim a stosowanym współcześnie kalendarzem gregoriańskim wynosi $13 \mathrm{dni}$ ). Motywem przewodnim pierwszego dnia było religijne oblicze miasta, ukazanego jako starodawny ośrodek kultury prawosławnej, przy czym za symbol tego dziedzictwa uznano dzwon. O 9 rano w Muzeum Sztuk Plastycznych (niegdysiejszy budynek zgromadzenia szlacheckiego) odsłonięto popiersie Aleksandra II. Rzeźba dłuta Alberta Czarkina jest pomniejszoną kopią pomnika cara-wyzwoliciela (autorstwa znanego rzeźbiarza, Aleksandra Opiekuszyna), który został wzniesiony w Rybińsku (obwód jarosławski) w $1914 \mathrm{r}$. i przetrwał zaledwie cztery lata. O godzinie $10 \mathrm{w}$ soborze św. Zofii rozpoczęła się dwugodzinna liturgia, w której uczestniczyły jedynie zaproszone wcześniej osoby. Stamtąd w południe wyruszyła procesja, kierująca się do pomnika postawionego z okazji 1000-lecia istnienia państwowości rosyjskiej, gdzie odprawiono nabożeństwo z kazaniem. O godzinie 13 na zlokalizowanym nieopodal placu odbyło się półgodzinne przedstawienie Historia państwa rosyjskiego. Następnie zaprezentowano odrestaurowaną salę władcy (грановитая палата) na kremlu. W tym momencie program ulegał rozszczepieniu. O godzinie 17 na placu przy kompleksie sportowym Maneż odsłonięto pomnik ku czci nowogrodzkiego pospolitego ruszenia w wojnie ojczyźnianej 1812 r. Godzinę później w filharmonii wybrzmiały pierwsze dźwięki zamkniętego dla szerszej publiczności dwuipółgodzinnego koncertu akademickiej orkiestry symfonicznej filharmonii petersburskiej pod dyrekcją Aleksandra Dymitriewa, z udziałem solistów Teatru Maryjskiego. O 21.30 nad rzeką Wołchow urządzono półgodzinny pokaz pirotechniczny zamykający pierwszy dzień obchodów. Popołudniowo-wieczorny program był zróżnicowany, można było przebierać w ofercie kulturalnej i rozrywkowej. W różnych częściach miasta odbywały się koncerty: swoje umiejętności prezentowali najwprawniejsi dzwonnicy, w paradach kroczyły orkiestry dęte, występowały zespoły chóralne, a także artyści grający na instrumentach ludowych, nie zabrakło również lokalnych zespołów uprawiających lżejszą muzykę. Chętni mogli wydawać pieniądze na jarmarkach, gdzie sprzedawano produkty rolnicze i rzemieślnicze. Jeszcze inni mieli okazję uczestniczyć w otwarciu festiwalu rekon- 
strukcji historycznych albo obejrzeć na świeżym powietrzu film o historii i kulturze Nowogrodu Wielkiego ${ }^{29}$.

Drugi dzień obchodów miał w zamyśle organizatorów pokazać ziemię nowogrodzką jako małą ojczyznę wielkiego kraju. O godzinie 9 otwarto na kremlu wystawę „Grodzisko Ruryka - najstarsza rezydencja książęca”. Dwie godziny później odbyła się uroczysta ceremonia odsłonięcia wysokiego na 2,6 metra i ważącego 40 ton „Kamienia książęcego”, na którym wcześniej wyryto fragment latopisu, mówiący o wezwaniu Ruryka ${ }^{30}$. Zamknięta dla ogółu publiczności uroczystość niemal dosłownie przeniosła zaproszonych uczestników w czasie, o co zadbali rekonstruktorzy (jednym z punktów programu był IV Festiwal Rekonstrukcji Historycznej): goście przybywali na miejsce w łodziach, a na wzgórzu nad Wołchowem „stacjonowali” wojowie z IX w. O godzinie 15 na głównym placu miasta odbyła się oficjalna ceremonia otwarcia uroczystości jubileuszowych, którą najpierw uświetniła odprawa kawaleryjskiej eskorty honorowej prezydenta FR, a następnie - pochód poszczególnych rejonów obwodu nowogrodzkiego oraz organizacji Nowogrodu Wielkiego. Kolejnym ważnym punktem programu było przyjęcie gości przez p.o. gubernatora obwodu, połączone z wręczeniem odznaczeń państwowych. Natomiast wieczór miał charakter typowo rozrywkowy - wypełnił go plenerowy koncert gwiazd rosyjskiej estrady. Podobnie jak pierwszego dnia jubileuszu, także i tym razem chętni mogli przebierać w programie kulturalnym, wybierając zgodnie ze swoimi upodobaniami ambitniejsze lub typowo rozrywkowe wydarzenia; wspólną cechą ich wszystkich był rzecz jasna folklor. Ten sam duch przenikał trzeci dzień obchodów, uwydatniający momenty chwały rosyjskiego oręża na ziemi nowogrodzkiej. Jeśli ograniczyć się do rzeczy ważnych, godne wzmianki wydaje się tylko przedpołudniowe odsłonięcie panneau, wykonanego w technice płaskorzeźby na stelach miejsca pamięci „Miasto chwały wojennej” przy bulwarze Woskriesieńskim. Każda z czterech stel poświęcona jest innemu okresowi dziejów ziemi nowogrodzkiej: wiek X-1478 (Ruś aż do wcielenia Republiki Nowogrodzkiej do Wielkiego Księstwa Moskiewskiego), 1492-1721 (Ruś Moskiewska), 17211917 (Imperium Rosyjskie), 1917 po współczesność ${ }^{31}$. Pozostałe punkty programu albo miały luźny związek z ideowym przesłaniem jubileuszu, albo - jak popołudniowe loty pokazowe nad Wołchowem - były zorientowane na ludyczny charakter rocznicowych dni.

29 http://www.1150russia.ru/programma-yubileya.html (dostęp: 26.03.2015).

30 „И прия Рюрикъ власть всю одинъ, и пришед къ Ильмерю, и сруби городок надъ Волховом, и прозваша и́ Новъгород, и седе ту, княжа, и раздая мужемъ своимъ волости и городы рубити". Por. polskie tłumaczenie fragmentu latopisu traktującego o 862 r. - Powieść minionych lat, przeł. i oprac. F. Sielicki, Wrocław 1999, s. 15-16.

31 В Великом Новгороде открыли рельефб-панно на мини-стелах мемориала „Город воинской славы", http://news.novgorod.ru/news/101350/ (dostęp: 3.06.2015). 


\section{Przekaz medialny - relacje ogólnokrajowych kanałów telewizyjnych}

W dobie hegemonii informacyjnej mediów elektronicznych, najbardziej miarodajnym wskaźnikiem znaczenia, jakie władze Federacji Rosyjskiej nadają jakimś wydarzeniom, jest przekaz ogólnokrajowych kanałów telewizyjnych. Internet oddziałuje tutaj w znacznie mniejszym stopniu, zapewne na skutek niewielkiej dostępności, która ograniczona jest do większych ośrodków miejskich. Warto w takim razie przyjrzeć się odbiciu oficjalnych uroczystości 1150-lecia w programach informacyjnych.

Pierwszy kanał rosyjskiej TV poświęcił im ledwie 44 sekundy w wieczornym wydaniu wiadomości z 22 września 2012 r. (w żadnym innym ten temat się nie pojawił), wyznaczając siódmą pozycję w kolejności; więcej czasu przeznaczono na historię kota-kleptomana, który pod osłoną nocy okrada mieszkańców jednego $\mathrm{z}$ brytyjskich miast. $\mathrm{W}$ materiale zaakcentowano rozrywkowy charakter obchodów. Widz mógł dowiedzieć się, że nieopodal grodziska Ruryka odbyła się parada historycznych okrętów różnych epok zatytułowana Od Wariagów ku Grekom, uwieńczona wystrzałami armatnimi. Następnie odegrano scenę wezwania Ruryka do Nowogrodu oraz obrazy z pierwszych dni historii miasta. Potem na terenie grodziska ustawiono „pamiątkowy znak” - ważący 40 ton głaz nazwany „książęcym kamieniem". Ostatnim punktem programu był natomiast pokaz pirotechniczny nad Wołchowem ${ }^{32}$.

Jeszcze lakoniczniej (38 sekund) o nowogrodzkich obchodach informował 21 września 2012 r. kanał informacyjny Rosja 24. Owszem, w czterech zdaniach poświęconych obchodom udało się zmieścić nie tylko wiadomość o wydarzeniach towarzyszących uroczystościom - festiwalu sztuki dzwonniczej, koncertach orkiestr dętych, jarmarku i wystawach sztuki ludowej - ale również to, że ceremonie rozpoczęly się liturgią w soborze nowogrodzkiego kremla, po której uroczyście udano się pod pomnik Tysiąclecia Rusi ${ }^{33}$. Jubileusz początków państwowości ruskiej został zaś całkiem przemilczany przez kanał Russia Today, kierujący przekaz do nierosyjskiego audytorium, poszukującego alternatywy dla amerykańskiej CNN czy europejskiej EuroNews.

Najobszerniej obchody 1150-lecia rosyjskiej historii relacjonował kanał NTW. W chronologicznie pierwszym materiale z 21 września 2012 r. (skądinąd zrealizowanym przez petersburską filię NTW, w kręgu zainteresowania której znajduje się cała północno-zachodnia Rosja) ograniczono się do ogólnych informacji, bogatszych od wyżej omówionych tylko komunikatem o odsłonięciu popiersia Aleksandra II, i o obecności gubernatora obwodu leningradzkiego ${ }^{34}$. Następnego

32 В Великом Новгороде отмечают памятную дату: 1150 лет зарождения российской государственности, http://www.1tv.ru/news/social/216055 (dostęp: 3.06.2015).

33 Великий Новгород отмечает 1150-летие государственности Руси, http://rutv.ru/brand/show/ episode/159912 (dostęp: 3.06.2015).

34 В честь 1150-летия в древнем русском городе начались массовые гуляния, http://www.ntv. ru/novosti/338097 (dostęp: 3.06.2015). 
dnia, tj. 22 września 2012 r., zaprezentowano widzom trwający 2 minuty i 36 sekund reportaż z Nowogrodu Wielkiego. Korespondent rozpoczął go uwagą, że pomysł świętowania jubileuszu państwowości w mieście, które przez całe stulecia odmawiało przyłączenia się do jakiegokolwiek państwa, świadczy o poczuciu humoru, które zresztą od samego początku towarzyszy nowogrodzianom. Następnie dodał, że usytuowanie rezydencji legendarnego Ruryka nad Wołchowem nie jest dokładnie znane. Według słów reportera miejsce, z którego wzięła swój początek rosyjska państwowość, nie wywarłoby dziś na nikim wrażenia. To, jaką przeszłość skrywa wzgórze z ruinami zabudowań, uświadamia dopiero pamiętający zamierzchłe czasy głaz narzutowy z wygrawerowanym cytatem z latopisu. Inaczej niż w omówionych wyżej relacjach, o dzwonie wspomniano w kontekście wiecu, czyli tradycji parlamentaryzmu. W dalszej części korespondencji była mowa o handlowych tradycjach Nowogrodu, nie ustępującego w swoim czasie najpotężniejszym ośrodkom europejskim, a także o tym, że zasługuje on na miano „okna do Europy”, którym pozostawał na długo przed powstaniem Petersburga. Słowem, miasto wniosło istotny wkład w rozwój rosyjskiej państwowości i ma niejeden powód do dumy (z tonu wypowiedzi można wnioskować, że nie chodzi tylko o prekursorstwo w szyciu obuwia oddzielnie na prawą i lewą nogę, choć wtrącanie podobnych uwag sporo mówi o rzeczywistym stosunku do jubileuszu) ${ }^{35}$.

Dokonany przegląd pozwala bez trudu dostrzec wspólną cechę przekazu najbardziej opiniotwórczych mediów elektronicznych - uznanie lokalnego raczej, niż ogólnopaństwowego charakteru nowogrodzkich obchodów. Tym samym zostały one zdegradowane do rangi festynu. Żadnej relacji z uroczystości nie wzbogacono refleksją nad sensem uczczenia symbolicznej daty narodzin Rusi, nie zastanawiano się nad tym, jakie są źródła trwałości ruskiej (rosyjskiej) państwowości, nie próbowano dociekać, co z tego wszystkiego wynika dla kolejnych pokoleń. Nie przemilczano samego faktu świętowania w Nowogrodzie Wielkim jubileuszu 1150-lecia istnienia wspólnoty wschodniosłowiańskiej, natomiast pozbawiono go jakiegokolwiek znaczenia politycznego. Rzecz jasna, nikła obecność tego wydarzenia w telewizji nie była sprawą przypadku. Przeciwnie - odzwierciedlała ona poziom zaangażowania najwyższych władz oraz prawosławnej hierarchii kościelnej.

\section{Pokłosie: wirtualna wystawa 1150-lecia państwowości rosyjskiej}

Materialnym śladem jubileuszu 1150-lecia państwowości rosyjskiej jest wirtualna wystawa, zorganizowana $\mathrm{z}$ inicjatywy Federalnej Agencji Archiwów (Федеральное архивное агентство) і Państwowego Archiwum Federacji Rosyjskiej (Государственный архив Российской Федерации - GARF) przy aktywnym

35 В Великом Новгороде заложили камень в основание российской государственности в честь ее 1150-летнего юбилея, http://www.ntv.ru/novosti/338421 (dostęp: 3.06.2015). 
udziale siedmiu innych archiwów. Jak wiadomo z wcześniejszego omówienia, internetowa ekspozycja była sztandarowym przedsięwzięciem zaplanowanym przez pomysłodawców obchodów. Okoliczność ta skłania do uważnego przyjrzenia się jej zawartości. Wystawę tworzy jedenaście gablot, a każda z nich ukazuje inny okres dziejów państwa. A oto i one: państwo staroruskie; rozpad państwa staroruskiego na odrębne księstwa; wielkie księstwo moskiewskie i księstwa Rusi północno-wschodniej; powstanie i rozwój zjednoczonego (единое) państwa ruskiego; smuta; Carstwo Moskiewskie; Imperium Rosyjskie; rewolucja lutowa i upadek samowładztwa, Rząd Tymczasowy; rewolucja październikowa, państwo radzieckie; Związek Socjalistycznych Republik Radzieckich; rozpad ZSRR, powstanie Federacji Rosyjskiej. Zwraca uwagę nader niejednorodna rozpiętość czasowa poszczególnych okresów: rzuca się w oczy zwłaszcza rozczłonkowanie Rosji przedpiotrowej i kontrastujące z nim potraktowanie dwóch stuleci (XVIII i XIX w.) jako organicznej całości. Taki układ może zdezorientować widza nawykłego do innych podziałów, na przykład na epoki panowania Rurykowiczów i Romanowów. Twórcy wystawy obrali kryterium zmiany formuły państwowo-ustrojowej, nawet jeśli nie miała ona radykalnego charakteru, tj. nie wyważała ram systemu prawnego. Dyrektor GARF wyjaśniał w słowie wstępnym, że w centrum zainteresowania autorów projektu znalazła się „sama historia państwa rosyjskiego”, utożsamiana ponoć z „historią instytucji państwa rosyjskiego od ich powstania do współczesności". Toteż rdzeń wystawy tworzą „określające istotę państwowości rosyjskiej” zbiory praw, od Ruskiej Prawdy po konstytucję 1993 r. ${ }^{36}$ Deklaracja ta jest lustrzanym odbiciem referowanego wcześniej stanowiska D. Miedwiediewa, co nie powinno dziwić - dyrektor archiwum państwowego pełni $\mathrm{w}$ istocie służbę urzędniczą i realizuje dyrektywy przełożonych. Rzecz jednak w czym innym: obrona zaprezentowanego punktu widzenia napotyka praktyczne trudności, gdyż wymaga dowiedzenia, że akty prawne wiernie odzwierciedlały ducha rosyjskiego (a wcześniej ruskiego) systemu politycznego; to zaś koliduje ze świadomością żmudnych kolei budowania państwa prawnego w Rosji, zarówno w schyłkowej dobie caratu, jak i obecnie. Inaczej mówiąc, przesłanie omawianego projektu internetowego wydaje się zbyt optymistyczne, przypomina bardziej deklarację intencji niż konstatację.

Trafność koncepcji wystawy to sprawa dyskusyjna, natomiast trudno byłoby bronić realizacji zamysłu, bo ewidentnie nie wykazano się dbałością pod tym względem. Komentarzom wyraźnie brakuje nici przewodniej, najprawdopodobniej pisały je różne osoby, nie skonsultowawszy uprzednio spójnego przekazu. $\mathrm{W}$ rezultacie widz otrzymuje porcję źle skomponowanych informacji, po trosze $\mathrm{z}$ historii zdarzeniowej, po trosze $-\mathrm{z}$ historii problemowej. Nie zadbano ani o ciągłość narracji (np. omówienie Imperium Rosyjskiego zamyka się na panowaniu Katarzyny Wielkiej), ani o jej uporządkowanie. Dobór dokumentów także sprawia

36 С.[В.] Мироненко, 2012 год объявлен годом российской истории, http://www.rusarchives.ru/ statehood/mironenko.shtml (dostęp: 3.06.2015). 
wrażenie przypadkowości, mimo iż w zasobach archiwów-uczestników projektu znajdują się wszystkie niezbędne materiały. Zapoznanie się z wirtualną ekspozycją wymaga samozaparcia, szybko bowiem dochodzi się do wniosku, że nie spełnia ona swojego zadania i nie daje wystarczającego oglądu dziejów Rosji. Wprawdzie udostępniono fotokopie ważnych aktów prawnych (a raczej ich fragmentów), ale zabrakło wyjaśnień, które uświadomiłyby czytelnikowi znaczenie danych uregulowań. W zaprezentowanym wyborze dokumentów i w opisach trudno dopatrzeć się określonej tezy politycznej, ulegania przeterminowanym schematom interpretacyjnym czy tym bardziej złej woli twórców wystawy. Z pewnością jednak zmarnowano dogodną okazję, by pokazać osiągnięcia rosyjskiej kultury prawnej, czego dowodem jest brak choćby wzmianki o Michale Sperańskim. Konkludując: internetowa ekspozycja nie ma odpowiednio przemyślanej konstrukcji, sprawia wrażenie chaotycznego zbioru materiałów, a nie dając odwiedzającym należytego pojęcia o zapowiedzianej problematyce, nie spełnia swojego zadania. Być może jej rozmycie odpowiada niejasnym wyobrażeniom dzisiejszych elit o 1150-letnim dziedzictwie Rosji.

\section{Postscriptum: projekt ustanowienia nowego święta narodowego}

Wymownym postscriptum do świętowania jubileuszu 1150-lecia początków państwowości rosyjskiej bez nadmiernego entuzjazmu jest los niedawnej inicjatywy, mającej w zamyśle utrwalić (a może raczej: zaszczepić) długą metrykę wschodniosłowiańskiego organizmu politycznego w świadomości społecznej. Deputowani Dumy Państwowej z ramienia Liberalno-Demokratycznej Partii Rosji, Michał Diegtiariow (ur. 1981) i Aleksy Didienko (ur. 1983), wystąpili z propozycją zmiany ustawy $O$ dniach chwaty wojskowej i pamiętnych datach Rosji ${ }^{37}$ w taki sposób, aby uwzględniała ona symboliczną datę narodzin Rusi. Nie jest to pierwsza próba modyfikacji kalendarza państwowych rocznic, podejmowana przez partię Włodzimierza Żyrinowskiego - w obecnej, szóstej kadencji parlamentu reprezentanci tego środowiska kilkakrotnie występowali z podobnymi pomysłami, ale za każdym razem bez rezultatu. Jeśli najnowszy, datowany 15 stycznia 2014 r. wniosek nie pozostał bez echa, to stało się tak dlatego, że autorzy projektu nowelizacji nie ograniczają się w nim do uzupełnienia listy wydarzeń godnych uczczenia, lecz pragną także wyrugowania jednej $\mathrm{z}$ dat, $\mathrm{w}$ dodatku mającej status święta państwowego. Ciężar gatunkowy propozycji skłania do zapoznania się z motywacjami projektodawców: próba tak radykalnej ingerencji w system symboli organizujący pamięć

37 Omówienie ustawy zob. M. Banaszkiewicz, O symbolach, uroczystościach $i$ wychowaniu patriotycznym w Rosji, w: Rozpad ZSRR i jego konsekwencje dla Europy i świata, cz. 4: Reinterpretacja po dwudziestu latach, red. A. Jach, M. Kuryłowicz, Kraków 2012, s. 31-33. 
rosyjskiego społeczeństwa nie powinna być lekceważona, ponieważ mówi wiele zarówno o nastrojach części elit politycznych, jak i o preferencjach ich wyborców.

W uzasadnieniu projektu deputowani LDPR deklarują chęć dowartościowania Dnia Rosji. Ich zdaniem, obchodzona dotąd pod tą nazwą pamiętna data (12 czerwca), przypominająca o ogłoszeniu przez Federację Rosyjską deklaracji suwerenności państwowej, nie zakorzeniła się w świadomości społecznej, o czym świadczą badania opinii publicznej. Taki stan rzeczy, twierdzą autorzy, nie jest sprawą przypadku: „zdecydowana większość mieszkańców kraju nie chce łączyć wielkiego słowa „Rosja” z aktem politycznym, który był „zwiastunem tragicznego rozpadu ZSRR”, a przecież niepodobna zapomnieć o tym, że to „właśnie deputowani ludowi RSFRR jako jedni z pierwszych ogłosili suwerenność swojej radzieckiej republiki”. W opinii obu członków niższej izby parlamentu fakt ten przekreśla szansę uczynienia z corocznych uroczystości czerwcowych święta państwowego konsolidującego Rosjan ${ }^{38}$. Jednoznacznie negatywna z punktu widzenia Federacji Rosyjskiej ocena upadku Kraju Rad nie może budzić zdziwienia u przedstawicieli partii politycznej, otwarcie głoszącej przywiązanie do mocarstwowości, tym bardziej że co najmniej od dekady, tj. od słynnego orędzia prezydenta Putina, wygłoszonego przed Zgromadzeniem Federalnym w 2005 r., powyższy pogląd zyskał rangę nieomal aksjomatu nawet wśród polityków dystansujących się od radykalnych sił nacjonalistycznych. W tym miejscu ważniejsza wydaje się wszakże inna konstatacja: oto symbol nowego - w intencjach liberalno-demokratycznego otwarcia w dziejach państwa rosyjskiego, nie stał się mitem fundacyjnym Rosji poradzieckiej.

Inicjatorzy obwołania umownej daty prapoczątków Rosji świętem państwowym wybrali rocznicę uroczystości odsłonięcia przez Aleksandra II pomnika upamiętniającego Tysiaclecie Rusi (20 września nowego stylu). Twierdzą oni, że zachowane źródła historyczne pozwalają uznać $862 \mathrm{r}$. za początek procesu zjednoczenia plemion zamieszkujących równinę wschodnioeuropejską pod auspicjami władców z dynastii Rurykowiczów. Charakterystyczne jest rozmieszczenie akcentów w uzasadnieniu projektu: autorzy uznają za kluczowe nie faktyczne stosunki władzy na tamtych obszarach, lecz pierwszy odnotowany wysiłek zmierzający ku „centralizacji ziem ruskich dzięki aktywnej polityce zagranicznej dynastii Rurykowiczów”, wspieranej przez miejscową ludność. Zgodnie z założeniami projektodawców, nowy dzień w kalendarzu rocznic przypominałby o „porozumieniu między staroruskimi plemionami a wareskimi liderami o formie rządów na terytorium Rusi Północno-Zachodniej”. Pisząc o „klasycznej chronologii historii Rosji”, biorącej swój początek od 862 r., deputowani LDPR położyli nacisk na nieprzerwane trwanie wspólnoty politycznej, mimo wielokrotnego przesuwania granic, przenoszenia stolicy

38 Пояснительная записка к проекту федерального закона «О внесении изменений в статью 1 Федерального закона "О днях воинской славы и памятных датах России» и в статью 112 Трудового кодекса Российской Федерации», http://asozd2.duma.gov.ru/main.nsf/ (ViewDoc)?Open Agent\&work/dz.nsf/ByID\&EB21378905DBD8FC43257CCA0028524E, s. 1-2 (dostęp: 5.07.2015). 
i licznych zmian ustrojowych. Ten moment argumentacji pozwala dostrzec sens odwołania się do pomnika stojącego w Nowogrodzie Wielkim od czasów cara-wyzwoliciela: poza punktem wyjścia w IX w. nie istnieje taka data, która symbolizowałaby ponadtysiącletnią państwowość rosyjską. Najwyraźniej do tego samego wniosku doszli autorzy pomnika Tysiąclecie Rusi, skoro także oni nie potrafili oddać dziejów Rosji za pomocą trafiającej do wyobraźni, a zarazem czytelnej metafory ${ }^{39}$.

Projekt nowelizacji ustawy został dopuszczony pod głosowanie dopiero 30 czerwca 2015 r., co samo w sobie wiele mówi o „atencji”, z jaką go traktowano, gdyż według pierwotnego harmonogramu prac miał być rozpatrywany podczas sesji Dumy Państwowej już w październiku 2014 r. Zgodnie z przewidywaniami na czerwcowym posiedzeniu został on odrzucony ze względu na brak kworum: w głosowaniu wzięło udział ledwie 66 deputowanych, w tym 56 z partii Żyrinowskiego. Pozbawiona rumieńców, dwudziestominutowa dyskusja na posiedzeniu plenarnym nie wystawiła dobrego świadectwa intelektualnym zdolnościom mówców, odsłaniając ich nieszczególnie wysoki poziom kultury historycznej; warto jednak zapoznać się z nią, by raz jeszcze stwierdzić, że motywacje projektodawców były wyłącznie negatywne (chęć zdeprecjonowania Dnia Rosji), a wielowiekowa perspektywa znacznie przekracza horyzont umysłowy członków wszystkich frakcji parlamentarnych ${ }^{40}$.

Trudno o bardziej wymowne świadectwo stosunku rządzących do propozycji LDPR, niż zdawkowe uzasadnienie negatywnego stanowiska rządu w tej sprawie. W piśmie z 28 marca 2014 r. Sergiusz Prichod'ko, jeden z zastępców premiera, stwierdził, iż wydarzenie, do którego odwołują się projektodawcy (odsłonięcie pomnika Tysiaclecie Rusi) wprawdzie „miało duży społeczny rezonans”, ale współcześnie nie jest postrzegane jako coś znaczącego ${ }^{41}$. Trudno polemizować z tym twierdzeniem, kontestowanie go byłoby zaklinaniem rzeczywistości. Wszelako oficjalna konstatacja wysokiego przedstawiciela władzy wykonawczej uzmysławia niepowodzenie rosyjskich elit politycznych w uczynieniu obchodów 1150-lecia państwowości czymś więcej niż tylko serią mniej lub bardziej widowiskowych uroczystości. Nie sądzę, by uwiarygodniało to spotykany niekiedy pogląd, że Rosja (a także kraje WNP) reprezentuje odrębny typ kultury pamięci, a jej cechą dystynktywną miałby być stosunek do komunistycznej przeszłości ${ }^{42}$. Być może natomiast poświadcza to trafność interesującego i zasługującego na uważną lekturę studium

39 Ibidem, s. 2-3.

40 http://www.video-duma.ru/watch/?id=303230 (dostęp: 5.07.2015).

41 Заключение на проект федерального закона «О внесении изменений в статью 1 Федерального закона «О днях воинской славы и памятных датах России» и в статью 112 Трудового кодекса Российской Федераиии», вносимьй в Государственную Думу депутатами Государственной Думь М.В.Дегтяревым и А.Н.Диденко, http://asozd2.duma.gov.ru/main.nsf/ (ViewDoc)?OpenAgent\&work/dz.nsf/ByID\&BBDEB49CE5B38F1743257CCA0036DF8B, s. 1 (dostęp: 5.07.2015).

42 Tak nр. Ш. Требст, „Какой такой ковёр?” Культура памяти в посткоммунистических обществах Восточной Европь: попьтка общего описания и категоризации, „Аb Imperio” 4 (2004), s. 55-56. 
politologicznego Niny Szczerbininy, według której w sferze symbolicznej system polityczny Rosji wspiera się na archetypie władcy-bohatera ${ }^{43}$ ? Historykowi dziejów politycznych Europy Wschodniej, który, badając studnię pamięci i świadomości zbiorowej największej wspólnoty słowiańskiej, usiłuje dokopać się do zasilających ją źródeł głębinowych, interesująca może wydać się jeszcze inna hipoteza. Nie potrafiąc godnie uczcić swoich narodzin, współczesna Rosja oficjalna demaskuje nieumiejętność (czyżby niemożność?) znalezienia formuły łączącej różne formy ustrojowe (nie tylko jedyno- i samowładztwo, ale i republikanizm), a więc i odmienne wartości, składające się na kulturę polityczną Rusi ${ }^{44}$.

\section{Uwagi podsumowujące - próba interpretacji}

W poszukiwaniu przekonującego naukowego objaśnienia istoty jubileuszowych uroczystości rosyjskiej monarchii w 1862 r. nader pomocna wydaje się wskazówka wytrawnej badaczki dziejów rewolucji francuskiej. Analizując świat pojęć XVIII-wiecznych rewolucjonistów i realizowaną przez nich politykę symboliczną, pisała ona: „[Święto] ma całkiem nową więź społeczną uczynić wyraźną, wieczną i nietykalną"45. Na pierwszy rzut oka przywołanie tej konstatacji sprawia wrażenie niedorzeczności, skoro obchody tysiąclecia istnienia państwowości rosyjskiej podkreślały ciągłość dziejową. Wszelako z punktu widzenia propagatorów reform, lansujących przemiany na łamach liberalnej prasy, drugie millennium historii Rosji miało urzeczywistniać ideały wolności i równości poddanych-obywateli. W tym sensie nowogrodzkie obchody nadawały wyższą sankcję wartościom uświęcającym odmieniony porządek społeczny (nie polityczny), a więc kwestionującym sztywne hierarchie bazujące na metryce urodzenia. Powyższe twierdzenie nie oznacza bynajmniej, iż Aleksander II i jego najbliższe otoczenie kierowali się pobudkami egalitarystycznymi. Jednakże święto akcentujące wspólnotę losów niejako bezwiednie niweluje nierówności ${ }^{46}: \mathrm{w}$ obliczu wielu wieków historii, której przecież niepodobna podzielić na historię poszczególnych warstw, społeczne dystynkcje członków zbiorowości

43 Н.Г. Щербинина, Мифо-герочческое конструирование политической реальности России, Москва 2011.

${ }^{44}$ Nawiasem mówiąc, powyższa konstatacja potwierdza trafność dokonanego przez współczesną niemiecką badaczkę rozróżnienia między miejscem pamięci a mitem politycznym. Lieux de mémoire nie są wyłączną własnością nosicieli określonej pamięci, zaś mit polityczny nie toleruje wieloznaczności i odzwierciedla jednoznaczną wizję sprawujących władzę, która ma zdominować przestrzeń publiczną; H. Hein-Kircher, „Mityczne odczytanie rzeczywistości”. Konstrukcje rzeczywistości, funkcje i wplyw mitów politycznych na kulturę pamięci, w: Polsko-niemieckie miejsca pamięci, t. 4: Refleksje metodologiczne, red. r. Traba, H.H. Hahn, współpr. M. Górny, K. Kończal, Warszawa 2013, zwł. s. 126-129.

45 M. Ozouf, Święto rewolucyjne 1789-1799, Warszawa 2008, s. 17.

46 To tłumaczy, dlaczego tak dużą wagę do uroczystego świętowania przykładali architekci porewolucyjnego ładu we Francji. Zob. J. Baszkiewicz, Nowy człowiek, nowy naród, nowy świat. Mitologia i rzeczywistość rewolucji francuskiej, Warszawa 1993, s. 148. 
przestają mieć znaczenie. W tej i tylko w tej części (a nie w egzaltowaniu się rzekomo najważniejszym politycznym kontekstem zagadnienia) uprawniona wydaje się klasyczna interpretacja przywoływanego już Richarda Wortmana: realizowany przez cara-wyzwoliciela „scenariusz władzy”, zakładający wdzięczność niższych warstw za poprawę ich doli, na przekór swojemu wykonawcy faktycznie katalizował rozszczepienie tradycyjnej legitymizacji monarchii.

Silna jest pokusa, by odpowiedzialnością za ostateczny kształt jubileuszu 1150lecia obarczyć W. Putina, który w połowie 2012 r. ponownie objął urząd prezydenta Federacji Rosyjskiej i nie sprostał deklaracjom ex post zawartym w swoim własnym wystąpieniu przed połączonymi izbami parlamentu z 12 grudnia tegoż roku. Tym silniej musi kłuć w oczy obserwatora rosyjskiej polityki otwierający niniejszy artykuł cytat z tego przemówienia. Jest wysoce prawdopodobne, że działanie to nie było przypadkowe: tym sposobem, przejąwszy ster rządów, Putin spostponował koncepcję D. Miedwiediewa, odwołującą się - przynajmniej w sferze retorycznej - do liberalnego dziedzictwa epoki wielkich reform. W strategię tę wpisuje się szereg programowych wystąpień publicznych, kokietujących środowiska konserwatywne (nie tylko w samej Rosji) ${ }^{47}$. Sygnalizowałem wszakże na początku tego tekstu zamiar interpretacyjnego skierowania się w inną stronę, toteż nie rozwijam tego wątku, z pewnością wartego szczegółowej analizy.

Być może bowiem należy odrzucić prostolinijne wytłumaczenia, zrzucające niepowodzenie obchodów 1150-lecia państwowości rosyjskiej na niefrasobliwość obecnych elit politycznych, i pokusić się o głębszą refleksję. Mimo jaskrawych różnic między dwoma omawianymi jubileuszami, daje się wyczuć w nich ten sam (choć o różnym natężeniu) dysonans. Świadomi uczestnicy święta podkreślającego ciągłość największej słowiańskiej organizacji państwowej musieli zastanawiać się nad aksjologicznym umocowaniem kolejnych hipostaz Rosji. Paradoksalnie, „chybiona” rocznica 2012 r. tylko podkreśliła immanentną niespójność przekazu ${ }^{48}$ sprzed półtora wieku. Mąż stanu, naoczny świadek ówczesnej fety z satysfakcją notował, że „przeszłość ożywała przed teraźniejszością. Stary Nowogród jednoczył się z dzisiejszym”. Działo się to niejako na przekór tym władcom, którzy „zbierając ruskie ziemie" okrutnie łamali opór nowogrodzian: Iwana III oraz Iwana IV. Tym samym - zdawał się twierdzić memuarysta - ostatecznie triumfowała tradycja wolnościowa ${ }^{49}$. Przytoczona relacja z jednej strony dowodzi, jak silna była na początku

47 Zob. poświęcony temu problemowi blok tekstów w „Przeglądzie Politycznym” 130 (2015), s. $20-57$.

${ }^{48}$ Owa niespójność jest funkcjonalnie uzasadniona i nie powinna być potępiana. Jak zauważył polski historyk idei, „każdy system legitymizacyjny, żeby działał, musi być niespójny. Mówi się różne rzeczy różnym adresatom i różne grupy społeczne, dążąc do realizowania swoich dążeń, też używają różnego języka lojalności” - M. Janowski [głos w dyskusji o problemach refleksji humanistycznej], w: Historia - dziś..., s. 334.

49 [П.А. Валуев], 8-е сентября 1862 года. Из воспоминаний современника, „Русская старина” 57 (1888), styczeń, s. 6-7. 
lat 60. XIX w. wiara w możliwość pogodzenia samowładztwa z liberalizmem. Z drugiej jednak - aż nadto wyraźnie pokazuje, że już wówczas uświadamiano sobie, iż rosyjska tradycja polityczna nie jest bynajmniej monolityczna. Otóż, po upływie 150 lat powyższa konstatacja tylko zyskała na sile. Społeczeństwo pluralistyczne nie da sobie wmówić jednorodności, jego członkowie identyfikują się z różnymi tradycjami ${ }^{50}$. Okoliczność ta sprawia, że nader trudno zharmonizować wymowę obchodów państwowości, przy czym uwaga ta nie dotyczy samej tylko Rosji.

Przebieg uroczystości 2012 r. skłania do namysłu nad trwałością zabiegów upamiętniania czy raczej długowiecznością symboli umacniających więzy wspólnotowe. Elity usiłują rozpropagować określony przekaz (i nieodłączny mu system wartości) po to, by zbiorowość stała się autentyczną wspólnotą, połączoną mocną nicią porozumienia. Granicę skuteczności tych zabiegów i ich zdolności mobilizacyjnych wyznacza istnienie emocjonalnego stosunku ludzi do przedmiotu upamiętnienia, choćby daty lub pomnika ${ }^{51}$. Prawidłowość tę znakomicie ilustruje zmieniający się w czasie odbiór pomnika Tysiaclecie Rusi, ewoluujący od fascynacji do obojętności, a także los inicjatywy uczynienia 20 września świętem narodowym. Trudno doszukiwać się tu czegoś niezwykłego, zjawisko to opisał Jay Winter, profesor Uniwersytetu Yale zajmujący się badaniem związków między historią i pamięcią. Amerykański historyk zauważył, że miejsca pamięci trwają dopóty, dopóki ludzie skłonni są przydawać im znaczenie, nie tylko (i nawet nie zwłaszcza) jako symbolowi czegoś istotnego w procesie dziejowym, lecz przede wszystkim jako dyrektywie moralnej. Skoro w zamyśle konstruktorów lieux de mémoire mają pozostawać punktami odniesienia dla kolejnych pokoleń odbiorców, niezbędny jest czynny udział tych ostatnich: nie wystarczy sama tylko absorpcja niegdysiejszych znaczeń, trzeba wciąż nadawać nowe. Miejsca pamięci (słowo „pamięć” pełni tu rolę metafory dla narracji o przeszłości zgodnej z intelektualnym bagażem tych, którzy już dawno nie żyją) nie są wieczne, choć inicjatorzy publicznych obchodów robią co $\mathrm{w}$ ich mocy, by termin ich trwałości wydłużyć w nieskończoność. W rzeczywistości proces rozpadu jest naturalny, a tym, co czyni go nieuchronnym, jest stopniowo zanikająca potrzeba łączenia życia tu i teraz z konkretnymi wydarzeniami odległej przeszłości. Nie oznacza to bynajmniej spadku zainteresowania historią. Po prostu stare potrzeby ustępują nowym, te natomiast mogą zostać zaspokojone tylko przez inne historie i przypominające je miejsca pamięci ${ }^{52}$.

${ }^{50}$ Nie dostrzega różnolitości rosyjskich tradycji politycznych (podobnie jak faktu, że na $2012 \mathrm{r}$. przypadł opisywany tu jubileusz) i wynikających z niej trudności konstruowania koherentnego wzorca patriotycznego autor tekstu syntetyzującego politykę historyczną Rosji w ostatnich kilkunastu latach: W. Materski, Polityka historyczna Federacji Rosyjskiej po 2000 r., „Dzieje Najnowsze" 4 (2014), t. 46, s. 93-115, zwł. s. 104.

${ }^{51}$ Por. R. Traba, Dwa wymiary historii. Szkic na otwarcie, w: idem, Przeszłość w teraźniejszości. Polskie spory o historię na poczatku XXI wieku, Poznań 2009, s. 28-29.

52 J. Winter, Sites of Memory, w: Memory. Histories, Theories, Debates, ed. S. Radstone, B. Schwarz, New York 2010, s. 312-313, 324. 
„Spoistość upamiętnienia”53 początków państwowości rosyjskiej w 2012 r. na tle obchodów 1862 r. wypadła niepokojąco. Nic w tym zresztą dziwnego: Rosjanie nie podjęli „pracy pamięci”, a „obowiązku pamiętania” nie łączą z aktem fundacyjnym swojej wspólnoty politycznej ${ }^{54}$. Podsumowując badania nad pamięcią historyczną pokolenia Rosji zreformowanej, współczesna rosyjska badaczka zwróciła uwagę na przemożne społeczne pragnienie dokonania historycznej samoidentyfikacji, połączone z chęcią stworzenia tożsamości zbiorowej ${ }^{55}$. Trudno oprzeć się wrażeniu, że dzisiejsze społeczeństwo rosyjskie nie ujawnia podobnych inklinacji ${ }^{56}$. Nie świadczy to wszelako o przeterminowaniu liberalnych ideałów epoki wielkich reform. Przeciwnie: pogłos ówczesnych dążeń i pragnień niesie się niczym echo wyrzutu, że stojące przed Rosją zadania nowego tysiąclecia dalekie są od urzeczywistnienia - mimo upływu kolejnych 150 lat.

\section{The Depreciation of the Grand Jubilee's Value: The Commemorative Celebration of the 1150th Anniversary of the Russian Statehood in Novgorod (2012)}

\section{Abstract}

The article is devoted to the subject of the 1150th anniversary of the Russian Statehood celebrated in September 2012. It was the liberal political commentary writings accompanying the original model of the jubilee celebrated in 1862 that was used as the point of reference of the rhetoric of the celebrations' initiator, the President of Russian Federation Dmitry Medvedev. This made the president of Russia to refer very often to the "Epoch of the Great Reforms" (the 1860s, and 1870s). The article describes the course of the jubilee celebrations with accompanying information campaign in the public mass media, as well as a failed legislative action to make the symbolic anniversary of the origins of the Russian Statehood a National Day. In the conclusions, the author distances himself from the absolutisation of political causes (customary

53 Określenie zaczerpnąłem z: Я. Зарубавель, Динамика коллективной памяти, w: Империя и нация в зеркале исторической памяти. Сборник статей, ред. И. Герасимов, М. Могильнер, А. Семенов, Москва 2011, s. 19.

${ }^{54}$ Obu terminów (z których tylko pierwszy wartościuje pozytywnie, w drugim upatrując pusty imperatyw) używa P. Ricoeur, Pisanie historii a przedstawienie przeszłości, „Przegląd Filozoficzny” 3 (2001), s. 263-264.

55 О.Б. Леонтьева, Историческая память и образы прошлого в культуре пореборменной России, w: Диалоги со временем: память о проилом в контексте истории, ред. Л.П. Репина, Москва 2008, s. 681.

56 Do identycznego wniosku dochodzi А.В. Святославский, История России в зеркале памяти. Механизм бормирования исторических образов, Москва 2013, s. 447-448. Nader wymowny w tym względzie jest fakt, że dwa najważniejsze ośrodki badania opinii publicznej - Wszechrosyjskie Centrum Badania Opinii Społecznej (ВЦиОМ) oraz Centrum Lewady (Левада Центр) - nie przeprowadziły ani jednego sondażu dotyczącego 1150-lecia państwowości rosyjskiej. Żenująco przedstawia się też wkład humanistyki i nauk społecznych: jubileusz nie znalazł naukowego odbicia na łamach zdecydowanej większości czołowych czasopism historycznych, politologicznych i socjologicznych. 
in the Polish writing blaming of the low political culture of the power elite) of the jubilee's failure. In the author's opinion, the main reason for the fiasco of the analysed enterprise resides in difficulties to create a coherent historical narration which would combine various political traditions and their fundamental values.

The research, making the fundamentals of the text, inscribe into the interdisciplinary studies - flourishing in Poland these days - of collective memory and identity. The research perspective chosen by the author makes it possible to enrich traditionally understood political history and history of ideas with the most recent achievements of historical anthropology. The purpose of this is to present not only a cultural context of symbolic dimension of ars regendi (with the problem of legitimization of power at the lead), but also to discover the sources for the durability of symbols as invisible bonds tying the political community.

\section{Депрециация великого юбилея: празднование 1150-летия российской государственности в Новгороде Великом (2012 г.)}

\section{Аннотация}

Статья посвящена празднованию 1150-летия российской государственности, которое проходило в Новгороде в сентябре 2012 г. За точку отсчета для риторики инициатора торжества, Президента Российской Федерации Д. Медведева, была избрана либеральная публицистика, сопровождавшая первообраз юбилея в 1862 г. Этот прием был продиктован фактом частого обращения тогдашнего главы России к «эпохе великих реформ» (60-е и 70-е гг. XIX в.). В тексте обсуждается ход юбилея и, посвященное ему, медийное освещение в средствах массовой информации. Была также представлена неудачная законодательная инициатива, предусматривающая признание символической годовщины начала Руси государственным праздником. Заключения текста отмежеваются от абсолютизирования политических причин (традиционное в польской публицистике сваливание вину на низкий уровень политической культуры элиты власти) неудачи юбилея. По мнению автора, главная причина провала, обсуждаемого мероприятия, заключается в трудностях создания связного исторического повествования, контаминирующего разнообразные политические традиции и лежащие у их основ ценности.

Исследования, являющиеся методологическим фундаментом текста, вписываются в междисциплинарное изучение памяти и коллективной идентичности, переживающее расцвет в Польше. Принятый исследовательский ракурс позволяет обогатить традиционно понимаемую проблемную политическую историю и историю идей свежайшими достижениями исторической антропологии. Целью такого действия является не только показать культурный контекст символического измерения ars regendi (во главе с проблемой легитимизации власти), но и выявление источников устойчивости символов, как незримых уз, скрепляющих политическое сообщество.

\section{Bibliografia}

Banaszkiewicz M., O symbolach, uroczystościach $i$ wychowaniu patriotycznym $w$ Rosji, w: Rozpad ZSRR i jego konsekwencje dla Europy i świata, cz. 4: Reinterpretacja po dwudziestu latach, red. Jach A., Kuryłowicz M., Kraków 2012, s. 23-37.

Banaszkiewicz M., Reformy a zmiana społeczna w Rosji Aleksandra II. Dymitr Milutin i gazeta „Gołos” w sporach o kształt oświaty i armii, rozprawa doktorska, Kraków 2015. 
Baszkiewicz J., Nowy człowiek, nowy naród, nowy świat. Mitologia i rzeczywistość rewolucji francuskiej, Warszawa 1993.

Baszkiewicz J., Władza, Wrocław 1999.

Bieleń S., Szanse modernizacji na tle osobliwości rosyjskiej polityki, w: Bariery modernizacji Rosji, red. S. Bieleń, A. Skrzypek, Warszawa 2014, s. 209-232.

Broda M., „Rosyjska idea” i problemy modernizacyjne Rosji, w: Bariery modernizacji Rosji, red. Bieleń S., Skrzypek A., Warszawa 2014, s. 55-72.

Connerton P., Jak społeczeństwa pamiętają, Warszawa 2012.

Goff J. le, Historia i pamięć, Warszawa 2007.

Hein-Kircher H., „Mityczne odczytanie rzeczywistości”. Konstrukcje rzeczywistości, funkcje i wpływ mitów politycznych na kulturę pamięci, w: Polsko-niemieckie miejsca pamięci, t. 4: Refleksje metodologiczne, red. Traba R., Hahn H.H., współpr. Górny M., Kończal K., Warszawa 2013, s. 123-132.

http://www.1150russia.ru/programma-yubileya.html (dostęp: 26.03.2015).

http://www.video-duma.ru/watch/?id=303230 (dostęp: 5.07.2015).

Kalinin I., The Struggle for History: The Past as a Limited Resource, w: Memory and Theory in Eastern Europe, ed. Blacker U., Etkind A., Fedor J., New York 2013, s. 255-265.

Korzeniewski B., Wprowadzenie. Przemiany pamięci społecznej z perspektywy teorii kultury polskie i niemieckie przestrzenie pamięci, w: Przemiany pamięci społecznej a teoria kultury, red. Korzeniewski B., Poznań 2007, s. 7-22.

Materski W., Polityka historyczna Federacji Rosyjskiej po 2000 r., „Dzieje Najnowsze” 4 (2014), t. 46, s. $93-115$.

Ozouf M., Święto rewolucyjne 1789-1799, Warszawa 2008.

Pomian K., Historia - dziś, w: Historia - dziś. Teoretyczne problemy wiedzy o przeszłości, red. Domańska E., Stobiecki R., Wiślicz T., Kraków 2014, s. 19-36.

Potulski J., Współczesny rosyjski dyskurs modernizacyjny, w: Fenomen Rosji. Pamiećc przeszłości i perspektywy rozwoju, cz. 2: Kontekst polityczny i gospodarczy, red. Diec J., Jach A., Kraków 2014, s. 119-139.

Problemy refleksji humanistycznej [dyskusja], w: Historia - dziś. Teoretyczne problemy wiedzy o przeszłości, red. Domańska E., Stobiecki R., Wiślicz T., Kraków 2014, s. 322-338.

„Przegląd Polityczny” 130 (2015), s. 20-57.

Ricoeur P., Pisanie historii a przedstawienie przeszłości, przeł. J. Górnicka, „Przegląd Filozoficzny" 3 (2001), s. 261-274.

Traba R., Dwa wymiary historii. Szkic na otwarcie, w: idem, Przeszłość w teraźniejszości. Polskie spory o historię na początku XXI wieku, Poznań 2009, s. 11-64.

Winter J., Sites of Memory, w: Memory. Histories, Theories, Debates, ed. Radstone S., Schwarz B., New York 2010, s. 312-324.

Буслаев А.И., Имперские юбилеи - тьсячелетие России (1862 год) и девятисотлетие крещения Руси (1888 год): организация, символика, восприятие обществом, rozprawa doktorska, Москва 2010.

В Великом Новгороде заложили камень в основание российской государственности в честь ее 1150-летнего юбилея, http://www.ntv.ru/novosti/338421 (dostęp: 3.06.2015).

В Великом Новгороде открыли рельеф-панно на мини-стелах мемориала «Город воинской славы», http://news.novgorod.ru/news/101350/ (dostęp: 3.06.2015).

В Великом Новгороде отмечают памятную дату: 1150 лет зарождения российской государственности, http://www.1tv.ru/news/social/216055 (dostęp: 3.06.2015).

В честь 1150-летия в древнем русском городе начались массовые гуляния, http://www.ntv. $\mathrm{ru} /$ novosti/338097 (dostęp: 3.06.2015).

Великий Новгород отмечает 1150-летие государственности Pуси, http://rutv.ru/brand/ show/episode/159912 (dostęp: 3.06.2015). 
Встреча с учёными-историками, http://www.kremlin.ru/news/12073 (dostęp: 3.09.2014)

Еремеева С.А., Монументальные практики коммеморации в России ХІХ и начала ХХ века, w: Образы времени и исторические представления: Россия - Восток - Запад, ред. Л.П. Репина, Москва 2010, s. 885-927.

Заключение на проект федерального закона "О внесении изменений в статью 1 Федерального закона "О днях воинской славы и памятных датах России» и в статью 112 Трудового кодекса Российской Федерации», вносимый в Государственную Думу депутатами Государственной Думы М.В.Дегтяревым и А.Н. Диденко, http://asozd2. duma.gov.ru/main.nsf/(ViewDoc)?OpenAgent\&work/dz.nsf/ByID\&BBDEB49CE5B38F17 43257CCA0036DF8B, s. 1 (dostęp: 5.07.2015).

Зарубавель Я., Динамика коллективной памяти, w: Империя и нация в зеркале исторической памяти. Сборник статей, ред. И. Герасимов, М. Могильнер, А. Семенов, Москва 2011, s. 10-29.

Заседание по вопросу подготовки к празднованию 1150-летия зарождения российской государственности, http://www.kremlin.ru/transcripts/12075 (dostęp: 3.09.2014).

Каспшыцка А., Реформа системы образования в России и формирование исторической памяти граждан, w: Fenomen Rosji. Pamięć przeszłości i perspektywy rozwoju, cz. 2: Kontekst polityczny i gospodarczy, red. Diec J., Jach A., Kraków 2014, s. 109-116.

Конорев С.В., Исторический миф в современном российском обществе: происхождение и соииокультурная роль, w: Кризисы переломных эпох в исторической памяти, ред. Л.П. Репина, Москва 2012, s. 325-333.

Кром М.М., Политическая антропология: новые подходы к изучению феномена власти в истории России, „Исторические записки” 122 (2001), z. 4, s. 370-397.

Лангеноль А., Общественная память после смены строя: сходства и различия между практиками памяти в посткоммунистических и постколониальных странах, „Ab Imperio” 1 (2004), s. 365-390.

Леонтьева О.Б., Историческая память и образы прошлого в культуре пореформенной России, w: Диалоги со временем: память о прошлом в контексте истории, ред. Л.П. Репина, Москва 2008, s. 636-681.

Майорова О., Бессмертный Рюрик: Празднование тысячелетия России в 1862 г., „Новое литературное обозрение” 43 (2000), s. 137-165, http://magazines.russ.ru/nlo/2000/43/ s6.html

Мироненко С.[В.], 2012 год объявлен годом российской истории, http://www.rusarchives. $\mathrm{ru}$ /statehood/mironenko.shtml (dostęp: 3.06.2015).

Пояснительная записка к проекту федерального закона «О внесении изменений в статью 1 Федерального закона "О днях воинской славы и памятных датах России» и в статью 112 Трудового кодекса Российской Федерации», http://asozd2.duma.gov.ru/main. nsf/(ViewDoc)?OpenAgent\&work/dz.nsf/ByID\&EB21378905DBD8FC43257CCA0028524E, s. 1-2 (dostęp: 5.07.2015).

Путин В.В., Послание Президента Федеральному Собранию, 12 декабря 2012 года, http:// kremlin.ru/events/president/news/17118 (dostęp: 3.09.2014).

Распоряжение Правительства РФ от 06.02.2012 N 153-р „О плане основных мероприятий по подготовке и проведению празднования 1150-летия зарождения российской государственности", www.consultant.ru/document/cons_doc_EXP_524549 (dostęp: 3.09.2014).

Святославский А.В., История России в зеркале памяти. Механизм формирования исторических образов, Москва 2013.

Требст Ш., „Какой такой ковёр?” Культура памяти в посткоммунистических обществах Восточной Европь: попьтка общего описания и категоризации, „Ab Imperio” 4 (2004), s. 41-78. 
Указ Президента РФ «О праздновании 1150-летия зарождения российской государственности» 3 марта 2011 года N 267, http://old.rs.gov.ru/sites/rs.gov.ru/files/1_-_Ukaz_Prezidenta_RF_03_03_2011.pdf (dostęp: 3.09.2014).

Уортман Р.С., Сценарии власти. Мифы и иеремонии русской монархии, t. 2: От Александра II до отречения Николая II, Москва 2004.

Щербинина Н.Г., Мифо-героическое конструирование политической реальности России, Москва 2011.

Mikołaj Banaszkiewicz (ur. 1983), dr, zajmuje się rosyjskimi tradycjami reformatorskimi, historią przedrewolucyjnego liberalizmu rosyjskiego oraz polityką historyczną Federacji Rosyjskiej; autor rozprawy doktorskiej Reformy a zmiana społeczna w Rosji Aleksandra II. Dymitr Milutin i gazeta „Gołos” w sporach o ksztalt armii $i$ oświaty (UJ, Kraków 2015, ss. 686) (mikolaj.banaszkiewicz@gmail.com).

Mikołaj Banaszkiewicz (ur. 1983), Ph.D., his interests include Russian Reformation traditions, history of pre-revolution liberalism in Russia and historical policy of the Russian Federation; he is the author of a doctoral dissertation "Reforms and Social Change in the Russia of Alexander II. Dmitry Milyutin and the "Golos" ("The Voice") Newspaper in the Dispute over the State of the Army and Education (Jagiellonian University, Cracow 2015, 686 pp.) (mikolaj.banaszkiewicz@gmail.com). 